Fundação Universidade Federal de Mato Grosso do Sul Faculdade de Medicina Veterinária e Zootecnia Curso de Medicina Veterinária

\title{
DOENÇA DO TRATO URINÁRIO INFERIOR FELINO
}

Louise Souza de Santa Rosa

Orientador: Prof(a). Drª. Veronica Jorge Babo Terra

Campo Grande - MS 


\title{
DOENÇA DO TRATO URINÁRIO INFERIOR FELINO
}

\author{
Louise Souza de Santa Rosa \\ Orientador: Prof(a). Dr ${ }^{\mathrm{a}}$.Veronica Jorge Babo Terra
}

CAMPO GRANDE - MS

NOVEMBRO DE 2010 
Fundação Universidade Federal de Mato Grosso do Sul Faculdade de Medicina Veterinária e Zootecnia Curso de Medicina Veterinária

\author{
Ata de Aprovação \\ Título: DOENÇA DO TRATO URINÁRIO INFERIOR FELINO
}

Acadêmico: LOUISE SOUZA DE SANTA ROSA

Orientador: Prof(a). Drạ . Veronica Jorge Babo Terra

Trabalho de Conclusão de Curso apresentado como requisito parcial para obtenção do grau em Medicina Veterinária, em 18 de novembro de 2010 e aprovado pela Banca Examinadora:

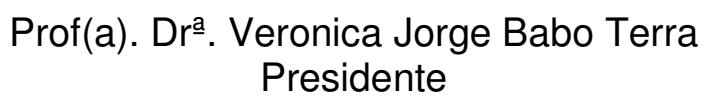

Prof. Dro․ Fernando Paiva

Prof. Ms. Fabiano de Oliveira Frazílio 


\section{SUMÁRIO}

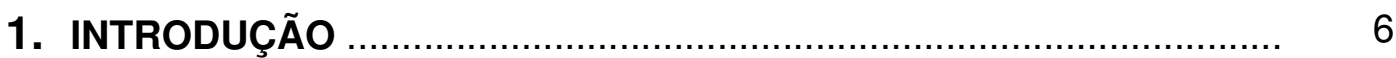

2. REVISÃO DE LITERATURA …................................................ 8

2.1. Etiologia ........................................................................ 9

2.1.1. Cristalúria ................................................................ 10

2.1.1.1. Urólitos ............................................................... 12

2.1.1.2. Cristal de Estruvita ............................................... 16

2.1.1.3. Cristal de Oxalato de Cálcio .......................................... 19

2.1.1.4. Tampão Uretral ............................................................. 20

2.1.2. Agentes Infecciosos ...................................................... 22

2.1.3. DTUIF x Cistite Intersticial Humana........................................ 24

2.1.4. Defeitos Congênitos ......................................................... 28

2.1.5. Neoplasias .................................................................. 29

2.1.6. Trauma ........................................................................ 29

2.1.7. Virais ......................................................................... 30

2.2. Sinais Clínicos ......................................................... $\quad 30$

2.2.1. Complicações ............................................................ 31

2.3. Diagnóstico ................................................................... 33

2.3.1. Diagnóstico por Imagem ................................................... 34

2.3.2. Exames Laboratoriais ................................................... 35

2.4. Propostas Terapêuticas ................................................. 37

2.4.1. Protocolo Anestésico ............................................................ 38

2.4.2. Reestabelecimento da Patência Uretral ................................... 39

2.4.3. Correção dos Desequilíbrios Hídrico, Eletrolítico e Ácido -

Básico

42

2.4.4. Correções e Cuidados Após a Desobstrução .............................. 44

2.4.5. Antibioticoterapia ............................................................. 45

2.4.6 Agentes Antiinflamatórios e Analgésicos ............................... 46

2.4.7. Amitriptilina ................................................................. 47

2.4.8. Antiespasmódicos ....................................................... 48

2.4.9. Glicosaminoglicanos ..................................................... 49

2.4.10. Tratamento Dietético................................................... 49

2.4.11. Intervenção Cirúrgica..................................................... 50

2.5. Prognóstico ....................................................................... 51

2.6. Prevenção ...................................................................... 51

2.6.1. Redução de Estresse .......................................................... 51

2.6.2. Dieta e Consumo Hídrico................................................. 53

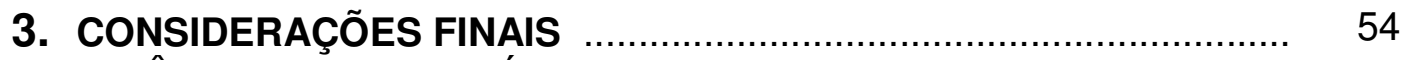

REFERÉNCIAS BIBLIOGRÁFICAS ........................................ 55 


\section{LISTA DE TABELAS}

Tabela 1 Composição de mineral de 11,697 urólitos felinos e 425 plugs uretrais realizada pelo Minnesota Urolith Center no ano de 2009*. Adaptado de OSBORNE, 2010b............................................

Pág.

Quadro 1 Relação das rações disponíveis no mercado brasileiro para tratamento de DTUIF. (Adaptado de Bowles, 2008). 


\section{LISTA DE FIGURAS}

Figura 1 Cálculo de estruvita felino, com núcleo de urato de amônio.

(Revista Veterinary Focus, 2007)

Figura 2 Urólitos de oxalato de cálcio com aspecto variável.

(Revista Veterinary Focus, 2007) ........................................... 13

Figura 3 Camadas do urólito (Revista Veterinary Focus, 2007)................... 14

Figura 4 Proporção de urólitos, estruvita e oxalato de cálcio, submetidos à análise durante as últimas três décadas. (Revista Focus, 2007)..... 15

Figura 5 Plug mucoso composto por estruvita, fragmentos celulares e proteínas. (Revista Veterinary Focus, 2007) ...................................

Figura 6 Hipótese corrente da inflamação neurogênica da bexiga na cistite idiopática felina. (Adaptado de Gunn-Moore, 2003)...................... 25

Figura 7 Persistência do úraco em felino diagnosticado através de cistografia. (Adaptado de Aleixo et al. 2007).

Figura 8 Felino macho apresentando hematúria, após cateterização urinária. (Adaptado de Pinheiro, 2009).

Figura 9 Evidência radiográfica de cálculos na bexiga e na uretra distal de felino obstruído. (Adaptado de Pinheiro, 2009)

Figura 10 Felino, macho, SRD, 2 anos e 6 meses, apresentando DITUIF obstrutiva. (Adaptado de Felício, 2009).

Figura 11 Enriquecimento ambiental de brinquedos para redução do estresse em gatos com DTUIF. (Adaptado de Hostutler et al. 2005). 


\section{INTRODUÇÃO}

Os gatos domésticos são freqüentemente acometidos por doenças do trato urinário inferior que caracterizam-se por apresentar manifestações clínicas similares, embora possam ter etiologia multifatorial e muitas vezes inderterminada (GUNN MOORE, 2003; RECHE Jr., 2003).

A expressão Doença do Trato Urinário Inferior de Felinos (DTUIF) é utilizada como termo diagnóstico para a descrição de distúrbios das vias urinárias em felinos domésticos, sendo mais freqüente em gatos machos, de um a dez anos de idade (OSBORNE et al., 2000), e que geralmente consomem ração seca e ingerem pouca água (SOARES et al., 2005).

Os sinais clínicos clássicos presentes são lambedura da genitália, hematúria, disúria/estrangúria, polaquiúria, com presença ou não de obstrução parcial ou completa. Os sintomas podem se agravar dependendo da duração da doença e do grau da obstrução, com o desenvolvimento de desidratação, acidose metabólica, alteração de eletrólitos (hipercalemia, hiperfosfatemia e hipocalcemia) e por fim, azotemia pós-renal, complicação grave que pode levar o animal ao óbito (OSBORNE et al., 2004).

Nas três ultimas décadas, os possíveis fatores etiológicos têm sido pesquisados e discutidos, e incluem agentes infecciosos; tampão uretral; urólitos; cistite idiopática/intersticial; alterações congênitas (persistência do úraco); causas dietéticas; neoplasias e traumas (BARSANTI et al., 2004). Dentre os fatores epidemiológicos que auxiliam no aparecimento desta enfermidade estão: raça, sexo, idade, estação do ano, dieta, obesidade, sedentarismo, confinamento, baixo consumo hídrico e estresse (BALBINOT et al., 2006). Alguns autores consideram também a castração e o contato exclusivo com o ambiente interno como fatores predisponentes (OSBORNE et al., 1992).

O diagnóstico pode ser obtido pelo histórico clínico e exame físico do paciente, além de exames complementares auxiliares, como exames radiográficos, ultrassonográficos e cistocospia, e os exames laboratoriais (BARSANTI et al., 2004). 
Muitos casos de DTUIF não obstrutiva são autolimitantes, e usualmente se resolvem, com ausência dos sintomas, dentro de sete a quatorze dias (NORSWORTHY, 2009).

Em caso de não desaparecimento dos sintomas, medidas terapêuticas são iniciadas de acordo com os sinais clínicos presentes. Já os casos obstrutivos são considerados emergenciais, pois caso não seja realizada a desobstrução, o animal poderá vir a óbito dentro de até 72 horas (WOUTERS et al., 1998). O tratamento baseia-se na desobstrução e controle das alterações eletrolíticas e metabólicas.

Este trabalho visa realizar uma abordagem geral do assunto com enfoque nos possíveis fatores etiológicos e nas diversas terapias existentes, com o objetivo de auxiliar o clínico veterinário que, eventualmente tenha que interceder um felino acometido de DTUIF, a reconhecer suas particularidades e alterações orgânicas, sabendo como abordá-las e tratá-las. 


\section{REVISÃO DE LITERATURA}

A DTUIF pode ocorrer em felinos de qualquer idade ou sexo. Entretanto, é mais freqüente em gatos na faixa etária entre um a dez anos, atingindo um pico de incidência entre 12 e 48 meses, sendo incomum o acometimento de animais com idade inferior a um ano (RECHE Jr. et al., 1998; WOUTERS et al., 1998; KRAIJER et al., 2003; HOSTUTLER et al., 2005). Lewis et al. (1987) afirmaram que nos filhotes, a mineralização do esqueleto induz à liberação de íons $\mathrm{H}_{+}$, que acidificam naturalmente a urina e tornam raro o aparecimento de urólitos de estruvita. Os machos são duas vezes mais acometidos que as fêmeas (OSBORNE et al., 2000). Segundo Lekcharoensuk et al. (2001), em relação às raças, os persas e siameses possuem maior predisposição para DTUIF.

Caracteriza-se por apresentar inúmeros fatores predisponentes como obesidade, sedentarismo, domesticação, estresse, convivência com outros felinos, manejos alimentar e sanitários incorretos, ingestão de ração seca e pouco consumo hídrico (devido à temperatura, disponibilidade ou gosto da água). O risco associado à castração não está relacionado com a idade da castração, nem com diminuição do lúmen uretral. Segundo Hotel (2000), em seu estudo com 263 gatos, não diferiram o número de casos com obstrução uretral entre os animais castrados e inteiros, além de que, em seu trabalho notou-se que os diâmetros uretrais de animais castrados e inteiros de mesma idade eram semelhantes. Não se sabe exatamente seu efeito nas complicações uretrais, porém foi encontrado aumento no número de fibrócitos na uretra de animais castrados, que poderia provocar menor distensibilidade uretral (BARSANTI et al., 2004). Entretanto, este resultado é controverso, pois nem todos os estudos confirmaram esse achado, e pode ser que não exista relação com a castração, como no estudo realizado por Reche Jr. et al. (1998), que não comprovou a relação entre o estado reprodutivo do animal e o desenvolvimento da DTUIF.

Porém, sabe-se que a castração leva na maioria das vezes, o animal à obesidade, e conseqüentemente ao sedentarismo e a diminuição nas atividades físicas. Essa hipoatividade promove a diminuição da freqüência de micção, alcalinizando $\mathrm{o} \mathrm{pH}$, favorecendo a formação de cristais e, posteriormente, de cálculos (LEWIS et al., 1987; MARKWELL \& BUFFINGTON, 1994; OSBORNE et al., 2004). 
Segundo alguns autores a estação do ano é predisponente para a ocorrência do maior número de casos de DTUIF. A maior freqüência é nos meses de inverno, pois a temperatura baixa conduz o animal à redução das atividades físicas (BALBINOT et al., 2006).

\subsection{Etiologia}

A doença do trato urinário inferior dos felinos caracteriza-se por disúria, polaquiúria, estrangúria, hematúria, e periúria, podendo ou não estar associada com cistite, uretrite e/ou urolitíase. A DTUIF leva frequentemente, a obstrução recidivante do fluxo de saída urinário principalmente em felinos machos (POST, 1979; GUNNMOORE, 2003; OSBORNE et al., 2004). Devido à causa desses sinais clínicos não ser completamente elucidada, com uma etiologia multifatorial complexa e muitas vezes indeterminada, chamada assim de idiopática, variações na nomenclatura têm surgido com relação à doença do trato urinário inferior nos gatos (BARSANTI et al., 2004), como por exemplo, síndrome urológica felina (SUF), cistite intersticial ou idiopática felina (CIF), e recentemente doença idiopática do trato urinário inferior dos felinos (DITUIF) (POST, 1979; WOUTERS et al., 1998; RECHE Jr., 2003; BARSANTI et al., 2004; OSBORNE et al., 2004).

Entre os fatores que potencialmente desencadeiam a DTUIF, podem-se destacar os defeitos anatômicos, alterações comportamentais, infecções do trato urinário, cistite inflamatória idiopática, urolitíase, neoplasia e tampões uretrais (GUNN-MOORE, 2003). A cistite idiopática ou intersticial felina é indiscutivelmente, a causa mais comum de DTUIF relatada mundialmente em gatos com idades entre um e dez anos (KRUGER et al., 1991; OSBORNE et al.,1995; GERBER et al., 2005 ). A urolitíase constitui a segunda causa e é responsável por cerca de 13 a 28\% das consultas dos gatos com DTUIF (KRUGER et al., 1991; OSBORNE et al.,1995; GERBER et al., 2005)

Dentre as diversas manifestações da DTUIF, a obstrução uretral recebe maior atenção, pois se não revertida a tempo pode levar o paciente ao óbito (WESTROPP et al., 2005). A obstrução urinária é definida como a interrupção do fluxo de urina, podendo ocorrer em qualquer local do trato urinário e tendo como conseqüência a interrupção da filtração renal (COWGILL, 2003). Esta é mais comum em machos do 
que em fêmeas, devido às características anatômicas da uretra do macho, por ser mais alongada, estreita e menos distensível (RECHE Jr. et al., 1998; WOUTERS et al., 1998; BARSANTI et al., 2004; GUNN-MOORE \& SHENOY, 2004). As obstruções podem ocorrer por três formas distintas, por oclusão mecânica, ocasionando obstrução intramural, por oclusão anatômica, levando à obstrução mural ou extramural e por oclusão funcional (MARWELL, 1998).

As principais causas de afecções intramurais compreendem os tampões uretrais, neoplasias e urólitos (KRUGER et al., 1991). Ainda, Lane (2009) já descreveu que possíveis obstruções uretrais podem ocorrer por coágulos associados à hematúria.

As causas de afecções murais ou extramurais mais freqüentes incluem estenoses uretrais por edema e/ou fibrose e também, em menor freqüência, neoplasias e lesões na glândula prostática (KRUGER et al, 1991).

Em contrapartida, a inabilidade de micção em virtude da excessiva resistência da musculatura do colo vesical ou da uretra na ausência de obstrução anatômica intraluminal ou extraluminal é definida como obstrução urinária funcional (FISCHER, 2001). A eliminação normal da urina requer uma coordenação no relaxamento do colo vesical e uretra durante a contração do músculo detrusor. Na obstrução funcional, o músculo detrusor pode contrair, mas a contração inapropriada da uretra ou colo vesical evita a micção completa (HURLEY, 1998). As causas comumente relatadas são os espasmos uretrais, o dissinergismo reflexo e o dissinergismo do esfíncter do músculo detrusor. A obstrução funcional em razão de espasmos uretrais ocorre freqüentemente após o felino ter sido submetido à manobra clínica para remoção intraluminal de debris. A irritação causada pela obstrução mecânica associada aos procedimentos de cateterização pode resultar em uma uretra bastante contrátil. Os traumatismos na coluna vertebral nas regiões lombar ou sacrococcígea, envolvendo a medula espinhal podem, também, resultar em lesões que comprometam o reflexo do esfíncter uretral (FISCHER, 2001).

\subsubsection{Cristalúria}

A composição dos cristais encontrados na urina de felinos com DTUIF pode ser de estruvita, oxalato de cálcio, estruvita associado com fosfato amorfo, estruvita associado com oxalato de cálcio, somente fosfato amorfo, somente urato amorfo, 
cistina e sílica (RECHE Jr. et al., 1998), sendo a cristalúria por estruvita a mais comum nos felinos (BUFFINGTON et al., 1997).

Quando um cristal de um tipo de mineral é formado no trato urinário podem surgir condições para que outros tipos de minerais sejam desenvolvidos, o que leva à formação de urólitos compostos ou mistos. Porém, os tipos de cristais presentes no trato urinário podem ser totalmente diferentes da composição do urólito. (OSBORNE, 2010a)

A formação de cristais nos gatos depende de alguns fatores como o sexo do animal, o estado reprodutivo, a obesidade, as formas de manejo incorretas e, principalmente o tipo de dieta e a freqüência com que o animal se alimenta o que pode interferir diretamente no pH urinário (BUFFINGTON, 2001). Alguns cristais necessitam que a urina seja mais ácida para se desenvolverem (oxalato de cálcio, cistina, xantina), e outros são formados na urina neutra ou alcalina (estruvita, fosfato de cálcio) (OSBORNE, 2010a).

A cristalúria pode ocorrer em felinos com trato urinário normal, sem sinais clínicos de DTUIF porque os cristais são eliminados pela urina antes de chegarem a um tamanho suficiente para ocasionar alterações clínicas. Porém, apesar de os cristais sozinhos não provocarem manifestações clínicas, isso não significa que a cristalúria constitui um achado normal, exigindo assim, um acompanhamento do paciente para evitar a formação de cálculos urinários e conseqüentemente, urolitíase (OSBORNE, 2010a).

A cristalúria também pode ser indicativa de doença subjacente subclínica em outros sistemas corpóreos. Por exemplo, cristais de urato ácido de amônio são encontrados em animais com alteração no fígado. Cristalúria de cistina resulta de uma desordem caracterizada por diminuição da capacidade de reabsorver a cistina. Assim, identificar o tipo de cristais encontrados na urina é importante, pois aponta para a provável causa da cristalúria (OSBORNE, 2010a).

A associação entre cristalúria e DTUIF não é suficiente para comprovar uma possível participação desses cristais no desenvolvimento do processo inflamatório das vias urinárias inferiores, porém não se deve excluir sua participação na formação dos tampões uretrais (RECHE Jr. et al., 1998). Embora a cristalúria seja assintomática, ela pode predispor, quando grave e persistente, ao desenvolvimento de urolitíase e, conseqüentemente a inflamação vesical e obstrução uretral (GUNN MOORE, 2003). 


\subsubsection{Urólitos}

Os urólitos ou cálculos são estruturas rígidas compostas predominantemente de cristais (90-95\%) e com quantidades mínimas de matriz orgânica formada por complexos de proteínas (5-10\%) (FORRESTER, 2004). Proteínas e glicosaminoglicanas foram detectadas nos urólitos, porém não se sabe se existe alguma contribuição dessas para a formação dos cálculos ou se são apenas redes em camadas onde os mesmos crescem. Além disso, alguns medicamentos, em quantidade excessiva também podem precipitar como cristais no trato urinário e serem incorporados ao urólito, como por exemplo, a sulfadiazina e o alopurinol, (OSBORNE, 2010a).

Os cálculos são encontrados em $95,5 \%$ dos casos no trato urinário inferior, principalmente na bexiga e na uretra (MELER \& PRESSLER 2010). A teoria mais proposta para explicar o início da formação dos urólitos é a da Precipitação Cristalização, que ocorre quando as quantidades dos cristais excedem sua solubilidade na urina, tornando-a supersaturada com determinado tipo de cristal e acarretando sua precipitação. De acordo com Lulich et al. (2004), a segunda teoria, da Matriz-Nucleação afirma que substâncias da matriz orgânica na urina são promotoras de um núcleo inicial que permite o crescimento do urólito por meio de precipitação de cristais. Já a teoria da Cristalização-Precipitação aponta a redução ou ausência de fatores de inibição da cristalização como o fator primário no início da formação do núcleo. Independentemente de qual teoria seria a mais exata, se sabe que a concentração dos cristais, retenção urinária favorecendo a precipitação de sais, o pH da urina, a diminuição de inibidores da cristalização na urina e a matriz proteinácea podem afetar a solubilidade destes cristais minerais, ocasionando a formação do cálculo (BARSANTI et al., 2004).

Segundo o Minnesota Urolith Center, os urólitos podem ser classificados como simples, mistos ou compostos, baseando-se no tipo e quantidade mineral presente nas diversas camadas. São classificados como simples os urólitos com predomínio de um mesmo mineral (maior ou igual a 70\%), recebendo o nome do próprio mineral, como por exemplo urólito de estruvita. Os compostos são quando apresentam $70 \%$ ou mais de minerais distintos em camadas diferentes e mistos aqueles que apresentam camadas com diversos tipos de minerais, sem que haja a 
predominância de um único mineral (composição menor que 70\%) (Figura 1) (OSBORNE et al., 1999).

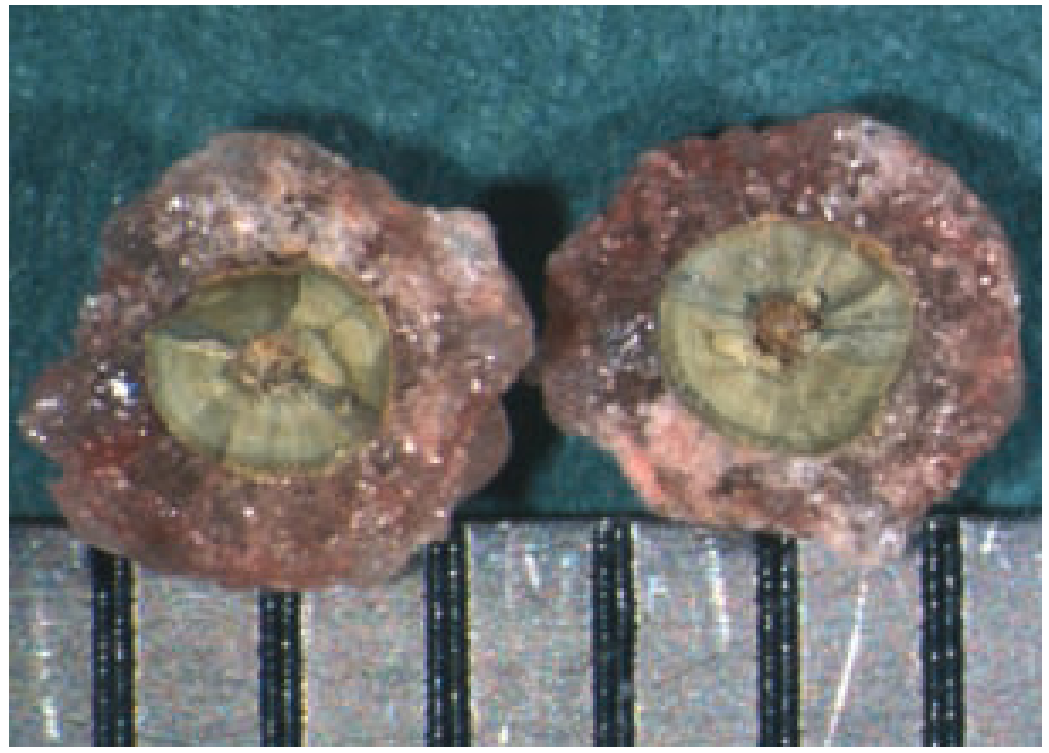

Figura 1 - Cálculo de estruvita felino, com núcleo de urato de amônio. (Fonte: Revista Veterinary Focus, 2007).

Apesar do aspecto físico de inúmeros cálculos constituir um bom indicador da sua composição (WEICHSELBAUM et al., 1998; OSBORNE et al., 1999), verificouse que todos os tipos de cálculos podem apresentar-se com uma grande variedade de formas, tamanhos e cores (Figura 2). É importante referir que o aspecto exterior de um cálculo raramente proporciona indicação sobre a composição do interior (MOORE, 2007).

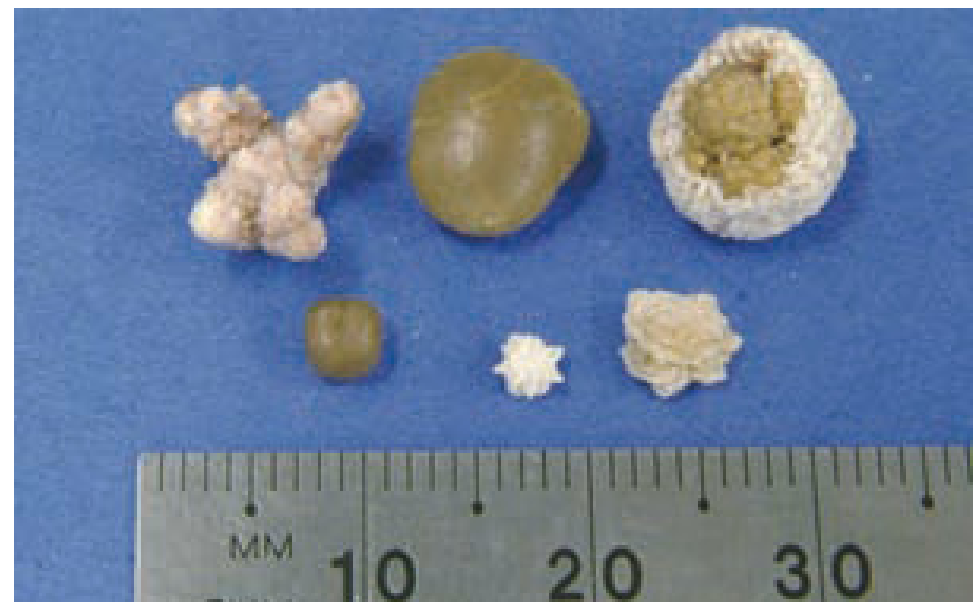

Figura 2 - Urólitos de oxalato de cálcio com aspecto variável.

(Fonte: Revista Veterinary Focus, 2007). 
Os urólitos são compostos por quatro camadas: o núcleo ou ponto de inicio, pedra ou massa do urólito, revestimento ou camada exterior e mais externamente, os cristais de superfície ou projeções superficiais (Figura 3). A identificação rigorosa dos tipos de minerais contidos em todas as camadas, principalmente no núcleo é fundamental. O manejo e o tratamento da urolitíase baseiam-se, sobretudo, nos elementos que compõem o núcleo, uma vez que dão origem ao cálculo. Todos os urólitos obtidos devem ser submetidos a uma análise quantitativa em laboratórios especializados (MOORE, 2007). Os urólitos podem ser recolhidos através de micções espontâneas, de descargas por urohidropropulsão, aspiração por cateter uretral, cistoscopia ou remoção cirúrgica (LULICH \& OSBORNE, 1992; LULICH et al., 1993).

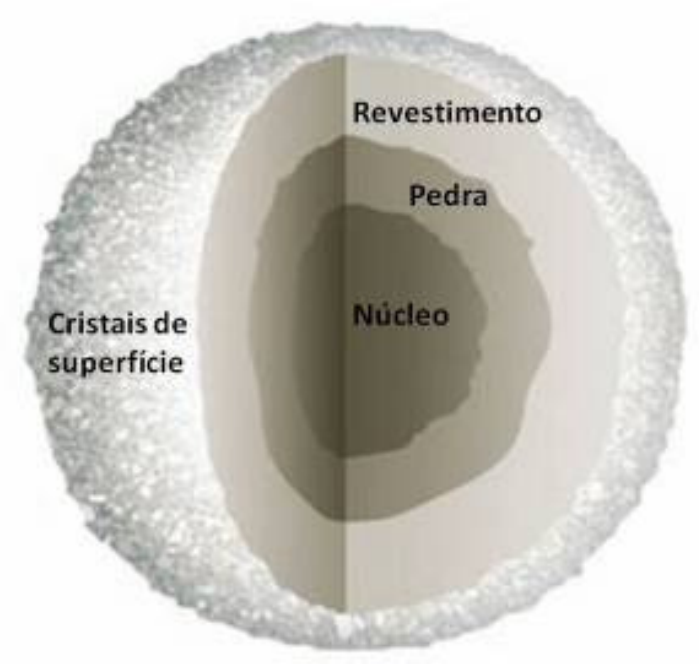

Figura 3 - Camadas do urólito.

(Fonte: Revista Veterinary Focus, 2007).

A prevalência de urólitos de estruvita e de oxalato em felinos modificou-se durante os últimos vinte anos. Em 1981, o oxalato de cálcio foi detectado em apenas $2 \%$ dos urólitos dos felinos submetidos à pesquisa no Minnesota Center - EUA, enquanto estruvita foi detectado em $78 \%$. No entanto, a partir de meados da década de 1980 até 2001, um aumento rápido e significativo na freqüência de urólitos de oxalato de cálcio ocorreu em associação com uma diminuição de reciprocidade na 
freqüência de urólitos de estruvita. Durante este período, o declínio na aparência natural de urólitos de estruvita associado com um aumento recíproco de urólitos de oxalato de cálcio pode ter sido associado a: 1) a utilização generalizada de uma dieta calculolítica projetada para dissolver urólitos de estruvita; 2) a modificação de dietas de manutenção e prevenção para minimizar cristalúria de estruvita (alguns fatores de risco dietéticos que diminuem o risco de urólitos de estruvita aumentam o risco de urólitos de oxalato de cálcio); 3) inconsistente acompanhamento da eficácia dos protocolos de manejo alimentar por exame de urina e radiografia (Figura 4). Contudo, desde 2002 até 2009 tem-se registrado um aumento dos urólitos de estruvita que constituem o tipo de cálculo analisado com maior freqüência nos EUA (OSBORNE, 2010b). Em Hong Kong, Itália e Reino Unido, os urólitos de estruvita constituíram o tipo mais comum, para o período de tempo em análise (1998-2000), com o oxalato em segundo lugar (STEVENSON, 2001). Em contrapartida, em 2005, no Canadá foi notificada uma percentagem idêntica de urólitos de estruvita e de oxalato presente nos felinos (HOUSTON et al., 2006). Verificou, portanto, que as diferenças observadas na proporção de cálculos de oxalato de cálcio e de estruvita nos diferentes países podem estar relacionadas com diversos fatores, incluindo o clima e o modo de vida do animal (STEVENSON, 2001).

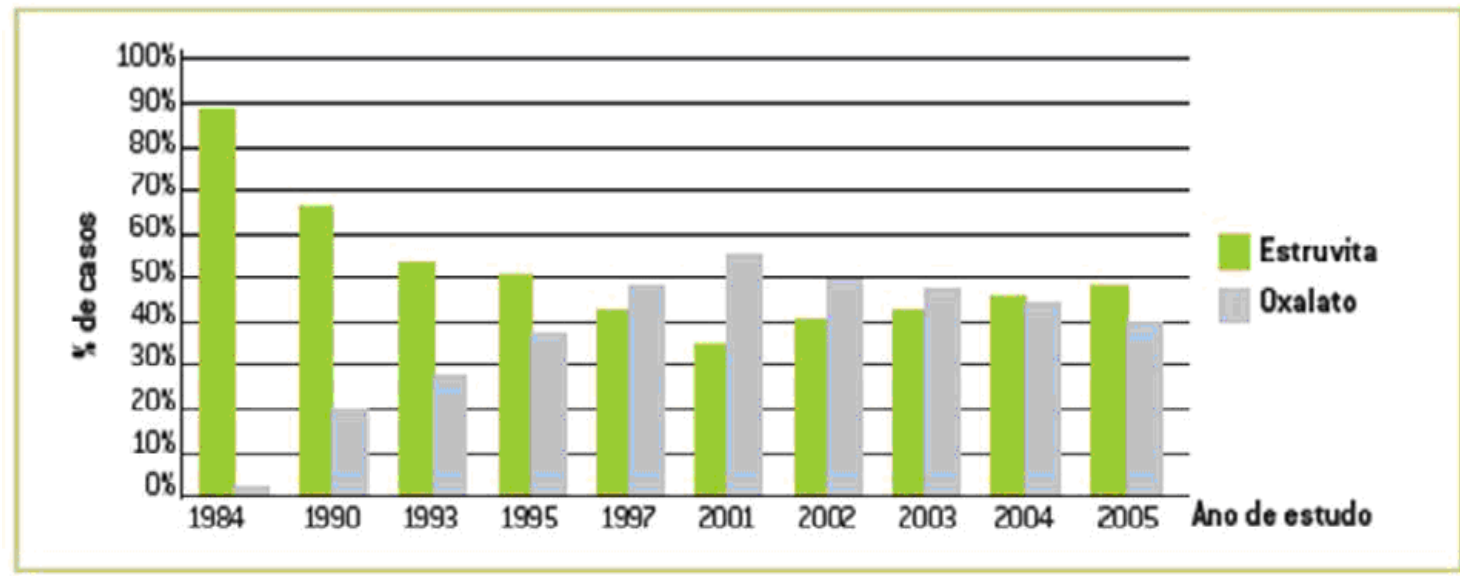

Figura 4 - Proporção de urólitos, estruvita e oxalato de cálcio, submetidos à análise durante as últimas três décadas. (Fonte: Revista Focus, 2007). 
Entre 1998 e 2003, nos EUA um total de 4.435 gatos foi analisado para estimar o número de recidivas dos urólitos. Dos animais que apresentavam urólitos no trato urinário, $54 \%(\mathrm{n}=2.393)$ tiveram urólitos de oxalato de cálcio, $41,1 \%(\mathrm{n}=$ 1821) tiveram urólitos de estruvita, $e<1 \%(n=221)$ tinham urólitos de urato de amônio. A recorrência dos urólitos foi determinada com base na análise do cálculo repetir em $5,5 \%$ dos gatos $(n=242)$ durante o período de estudo de seis anos. A composição dos urólitos das recidivas era a mesma que do inicial em quase todos os casos, variando de $83 \%$ a $96 \%$ dependendo do tipo de mineral. O intervalo médio para a primeira recorrência foi entre 1,8 e 2,4 anos. Os gatos adultos com diagnóstico inicial de oxalato de cálcio e de estruvita foram mais propensos a ter urólitos recorrentes identificados do que os gatos eram mais jovens (MELER \& PRESSLER, 2010).

\subsubsection{Cristal de Estruvita}

A estruvita ou fosfato triplo é o complexo de minerais (fosfato amônio magnesiano) mais freqüente na composição dos urólitos e tampões de muco observados no trato urinário felino. As raças referidas são o Himalaia, o Persa e o gato doméstico, com idade média de 5 a 7 anos (STEVENSON, 2001; HOUSTON, 2003). Porém, nos gatos Rex, Burmês, Abissínio, Azul da Rússia, Sagrado da Birmânia e Siamês, o risco de formação de cálculos de estruvita parece ser mais baixo (LEKCHAROENSUK et al., 2001).

A formação e desenvolvimento desses cristais ocorrem por meio de três mecanismos: cristais de estruvita estéreis, cristais de estruvita induzidos por infecção e tampões uretrais de estruvita. O primeiro mecanismo, relacionado aos cristais de estruvita estéreis está provavelmente associado a um conjunto multifatorial. Ao contrário do que ocorre na espécie canina, a maioria dos urólitos de estruvita é estéril no gato (OSBORNE et al., 1995). A redução do volume urinário e o conseqüente aumento da densidade urinária secundários à baixa ingestão de água, obesidade conseqüentemente o sedentarismo e a alta excreção de minerais (alguns calculogênicos) pela urina são fatores predisponentes para a formação do urólito (BUFFINGTON et al., 1990; OSBORNE et al., 1995). 
O segundo mecanismo, associado aos cristais de estruvita induzidos por infecção, está relacionado à urease microbiana. A infecção por organismos produtores de urease é rara em felinos, sendo observada apenas em gatos com menos de um ano de vida, em gatos idosos ou que tenham sido submetidos a procedimentos como uretrostomia perineal. A hidrólise da uréia pela urease leva à alcalinização da urina e à formação de uma grande quantidade de íons fosfato e amônio, que fazem parte da composição dos cristais de estruvita. E, por fim, o terceiro mecanismo, relacionado aos tampões uretrais de estruvita, sendo sugerido por diversos autores como resultante de uma associação dos fatores predisponentes dos cristais de estruvita estéril e dos induzidos por infecção. Este mecanismo é uma das causas mais comuns de obstrução uretral em gatos (OSBORNE et al., 1995).

Um estudo de casos clínicos destacou o aumento do risco pela administração de dietas com teores elevados de magnésio, fósforo, cálcio, cloreto e fibras, níveis moderados de proteína e baixos teores de gordura (LEKCHAROENSUK et al., 2001). As dietas contendo 0,15 a $1,0 \%$ de magnésio na matéria seca estão associadas à formação de urólitos de estruvita. Assim, recomenda-se utilizar dietas com cerca de 0,04\% de magnésio, que é suficiente para atender às necessidades dos felinos (OSBORNE et al., 1995). Contudo, a ação do magnésio depende da forma deste mineral (cloreto, óxido) e do pH da urina $(>6,5)$ (BUFFINGTON et al., 1990).

O aumento do volume urinário, mediante o uso de dietas enlatadas com alto teor de umidade, próprios para gatos, ou por meio de dietas com alto teor protéico é uma medida importante para se evitar a formação do urólitos. O uso das dietas assinaladas pode promover a acidificação do $\mathrm{pH}$ urinário, conseqüente a um conteúdo maior de aminoácidos sulfurados que serão catabolizados. O catabolismo de tais aminoácidos induzirá um aumento na proporção de $\mathrm{NH} 4+$ para $\mathrm{NH} 3$ e diminuição do PO4-3 em relação ao fósforo total (BUFFINGTON et al., 1994; OSBORNE et al., 1995).

Recentes estudos relatam que o peptídeo cauxin, excretado na urina de gatos do sexo masculino em alta concentração $(>1 \mathrm{mg} / \mathrm{mL}$ ) e auxiliador na hidrólise da felinine (precursor do ferormônio sexual) foi resposável por acelerar a formação de cristais de estruvita. A excreção urinária de cauxin inicia-se em felinos após 3 meses de idade, sendo maior a excreção em gatos adultos machos do que em femêas. A castração dos gatos machos reduz a excreção urinária. 
A variação na excreção de cauxin está relacionada à ocorrência de urolitíase contendo cristais de estruvita. Estudos epidemiológicos têm revelado que filhotes de felinos apenas apresentavam urolitíase devido a presença de cálculos urinários de estruvita, e que gatos machos foram mais suscetíveis a urólitos de estruvita do que gatas. A porcentagem de cálculos urinários de estruvita foi inferior em gatos castrados do que em gatos machos intactos. Assim, uma aumento na excreção de cauxin pode ser um fator de risco para ocorrência de urolitíase através da estimulação de cristalização de estruvita ( MATSUMOTO \& FUNABA, 2008).

Segundo Osborne et al. (2000), os alimentos úmidos reduzem em até três vezes a chance do desenvolvimento de DTUIF, diminuindo também recidivas. Sturgess et al. (2001) realizaram estudo com objetivo de avaliar a influência do armazenamento de amostras de urina no diagnóstico de cristalúria, e sua relação com a alimentação em gatos que nunca tiveram sinais de doença do trato urinário inferior. A urina foi mantida sob temperatura corporal, e submetida à urinálise em até 15 minutos após a colheita. Constatou-se maior probabilidade de encontrar cristais de estruvita em amostras de urina fresca, e de gatos alimentados com dieta mista (seca e úmida) com relação aos gatos alimentados somente com dieta úmida (enlatada). Este resultado pode decorrer do aumento da concentração de soluto e a tendência de formar urina mais alcalina nos animais alimentados com dieta mista. $A$ refrigeração de amostras de urina deve ser evitada quando o objetivo é avaliar seu sedimento quanto à cristalúria de estruvita. Segundo Smith et al. (1998) e Osborne et al., (2004) o consumo de ração seca acarreta em uma maior excreção de água para o bolo fecal, pois as fibras insolúveis presentes neste tipo de alimento, atuam osmoticamente atraindo água para o lúmen intestinal, desta forma, há uma tendência à diminuição da excreção de água na urina, deixando-a mais concentrada, favorecendo a formação de cristais e tampões.

Em relação ao fator $\mathrm{pH}$, segundo experimentos por Buffington \& Chew (1999), animais alimentados basicamente com dietas ricas em proteínas de origem animal, tendem a produzir urina ácida. Em contrapartida, animais que são alimentados com dietas ricas em cereais e vegetais tendem a formar uma urina alcalina. No Brasil, Reche Jr. et al. (1998) observaram que dois terços dos animais com DTUIF apresentavam cristalúria de estruvita e pH urinário médio de 7,09. Os gatos do grupo controle possuíam pH urinário médio de 5,94 e cristalúria de estruvita em $24 \%$. Além disso, não houve diferença significativa de $\mathrm{pH}$ urinário entre gatos 
com DTUIF obstrutiva e não obstrutiva. Conclui-se desta forma, que embora o pH urinário inferior a 6,5 não favoreça a formação de cristais de estruvita (LIMA et al., 2007), ele não inibe completamente sua formação (RECHE Jr. et al., 1998).

A ingestão de dietas altamente protéicas (50\% a 55\%) aumenta a excreção urinária de fósforo e reduz a absorção intestinal de cálcio, além de diminuir a concentração plasmática de potássio. Diante disso, a utilização desse tipo de dieta por longo período, requer uma avaliação periódica do animal, observando o comportamento orgânico frente a concentração sanguínea dos referidos minerais, uma vez que poderá ser necessário aumentar o teor, na dieta, de alguns desses elementos, especialmente o potássio (FUNABA et al., 1996).

\subsubsection{Cristal de Oxalato de Cálcio}

As raças Himalaia e Persa parecem mais predispostas ao risco de urolitíase por oxalato de cálcio. Até o momento não existe explicação para o aparente aumento do risco de formação de urólitos de oxalato de cálcio, embora seja associado ao uso freqüente de dietas acidificantes com restrição do teor de magnésio, de modo a controlar a formação de urólitos de estruvita. $\mathrm{O}$ pH ácido da urina persistente pode estar associado à acidose metabólica de baixa intensidade, que promove a mobilização óssea de carbonato e de fósforo para os íons tampão de hidrogênio. A mobilização simultânea de cálcio, associada à inibição da reabsorção deste mineral nos túbulos renais provoca o aumento da excreção urinária de cálcio (hipercalciúria). A probabilidade é três vezes superior de formação de urólitos de oxalato de cálcio em gatos alimentados com dietas formuladas para induzir que o $\mathrm{pH}$ urinário se mantenha entre 5,99 e 6,15 (LEKCHAROENSUK et al., 2001). No entanto, muitos gatos são alimentados com dietas acidificantes e apenas alguns desenvolvem hipercalcemia, acidose metabólica e urolitíase de oxalato de cálcio. Conseqüentemente, é importante levar em consideração fatores como a hiperabsorção gastrintestinal ou o aumento da excreção renal de cálcio em pacientes com maior susceptibilidade. O aumento da absorção intestinal de cálcio pode resultar do excesso de cálcio dietético, excesso de vitamina $D$ ou hipofosfatemia. Por outro lado, o aumento da excreção renal de cálcio pode ocorrer devido ao decréscimo da reabsorção tubular renal (por utilização de furosemida, corticosteróides, vitamina D) ou ao aumento da mobilização de cálcio das reservas 
do organismo ocasionando calciúria (acidose, hiperparatiroidismo, hipertiroidismo, excesso de vitamina D) (OSBORNE et al., 1995).

Um estudo de casos clínicos demonstrou que os gatos alimentados com dietas com teores reduzidos de umidade e de proteína apresentam maiores risco de urolitíase por oxalato de cálcio. Foi igualmente relatado aumento do consumo de água, do volume urinário e da excreção de fósforo na urina em felinos com administração de dietas ricas em proteínas, embora a excreção de cálcio não tenha aumentado. A depleção do volume intravascular e a concentração do volume urinário potencializam o risco de supersaturação da urina em cálcio e em oxalato. Os gatos alimentados com dietas úmidas apresentam cerca de 1/3 de probabilidade de desenvolver urólitos de oxalato de cálcio, comparados aos gatos que recebem alimentos com pouca umidade. Os alimentos ricos em umidade estão associados com o aumento de produção de urina menos concentrada, quando comparadas a dietas com pouca umidade. Tanto a restrição quanto a suplementação de magnésio dietético estão associadas ao maior risco de urolitíase por oxalato de cálcio em gatos, fazendo com que as dietas não tenham nem um teor muito restritivo e nem uma suplementação de magnésio (LEKCHAROENSUK et al., 2001).

Sugere-se que em humanos, a suplementação com cloreto de sódio permite aumentar a excreção urinária de cálcio. O sódio dietético (ou cloreto de sódio) e o teor de umidade do alimento são extremamente eficazes para estimular o consumo de água e a diurese em cães e gatos (BURGER et al., 1980). O aumento da diurese promove a diluição urinária e conseqüentemente, diminui a concentração de minerais de baixa solubilidade (STEVENSON \& MARKWELL, 2001).

O risco de formação de urólitos de oxalato de cálcio aumenta com a idade, pois os gatos idosos apresentam $\mathrm{pH}$ urinário acentuadamente mais baixo que os felinos mais jovens $(6,08+/-0,22$ vs. $6,38+/-0,22$, respectivamente). O modo de vida em ambientes fechados é também considerado um fator de risco para urolitíase por oxalato de cálcio (GERBER, et al., 2005).

\subsubsection{Tampão Uretral}

O tampão uretral ou "plug" geralmente é formado pela associação de uma matriz cristalina e uma matriz protéica que juntas formam os tampões mistos, apesar de existirem os de matriz única (Figura 5). A base da matriz cristalina pode ser 
constituída de oxalato de cálcio, porém a mais comum, desde 1891, é a de estruvita (Tabela 1) (BARTGES, 2003).

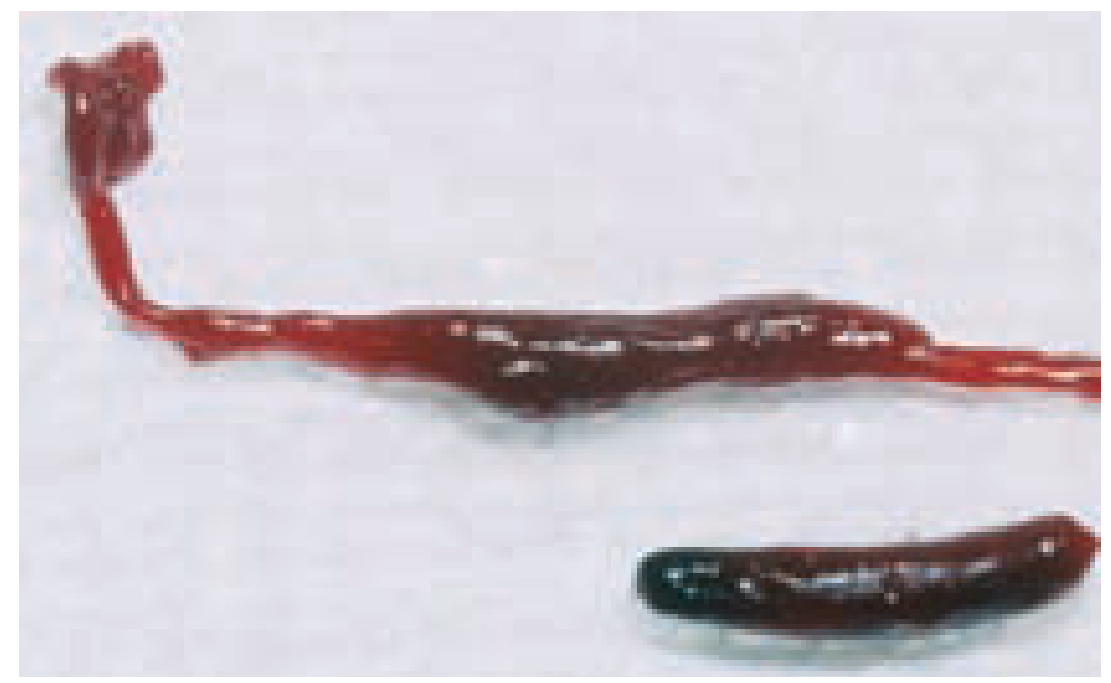

Figura 5 - Plug mucoso composto por estruvita, fragmentos celulares e proteínas. (Fonte: Revista Veterinary Focus, 2007).

Tabela 1 - Composição de mineral de 11,697 urólitos felinos e 425 plugs uretrais realizada pelo Minnesota Urolith Center no ano de 2009*. (Adaptado de Osborne, 2010b).

\begin{tabular}{|c|c|c|c|c|}
\hline $\begin{array}{c}\text { Tipo Mineral } \\
\text { Predominante }\end{array}$ & $\begin{array}{c}\text { Número de } \\
\text { Urólitos }\end{array}$ & $\%$ & $\begin{array}{c}\text { Número de } \\
\text { Plugs }\end{array}$ & $\%$ \\
\hline $\begin{array}{c}\text { Fosfato de } \\
\text { amônio } \\
\text { magnésio }\end{array}$ & 5,578 & 48 & 389 & 94 \\
\hline $\begin{array}{l}\text { Oxalato de } \\
\text { Cálcio }\end{array}$ & 470 & 40 & 1 & 0,2 \\
\hline $\begin{array}{c}\text { Fosfato de } \\
\text { Cálcio }\end{array}$ & 37 & 0,3 & 0 & 0 \\
\hline $\begin{array}{l}\text { Purinas (sais } \\
\text { de urato, } \\
\text { ácido úrico, } \\
\text { xantina) }\end{array}$ & 606 & 5 & 1 & 0,2 \\
\hline Cistina & 9 & $<0,1$ & 0 & 0 \\
\hline Silica & 9 & $<0,1$ & 0 & 0 \\
\hline Composto & 511 & 4,4 & 0 & 0 \\
\hline Matriz & 86 & 0,7 & 21 & 5,1 \\
\hline Misto & 118 & 1 & 3 & 0,7 \\
\hline Outros & 43 & 0,4 & 0 & 0 \\
\hline
\end{tabular}

* Analisados utilizando microscopia de luz polarizante e/ou espectroscopia infravermelha. 
A matriz protéica é constituída por mucoproteínas, albuminas e globulinas (BARTGES, 2003). Rhodes et al. (1992) realizaram estudos sobre a composição destes tampões e foi verificado o isolamento da mucoproteína de Tamm Horsfall em pacientes felinos com DTUIF e que esta proteína poderia constituir-se a matriz mucoprotéica à qual unem-se os cristais. Em contrapartida, Westropp et al. (1996) observaram a presença de proteínas como a albumina e frações de albumina como os principais componentes protéicos dos tampões uretrais, e que a mucoproteína de Tamm Horsfall seria um componente secundário.

A formação de tampões pode ocorrer na DTUIF por qualquer causa (OSBORNE et al., 1992). Entretanto, a maioria dos autores relatam a presença de urólitos como a principal causa para a instalação de tampões uretrais. A cistite idiopática foi relatada como fator predisponente para formação de tampões, devido a uma mistura de glicosaminoglicanos com urina formando um muco espesso (GUNNMOORE, 2003).

\subsubsection{Agentes Infecciosos}

A infecção bacteriana é incomum em gatos com DTUIF, porém, mesmo sendo infreqüente, corresponde a um dos possíveis fatores etiológicos relacionados ao desenvolvimento do processo inflamatório das vias urinárias nos felinos (GUNNMOORE, 2003; BARSANTI et al., 2004). Quando os achados de urinálise, cultura e antibiograma identificam infecção bacteriana, este animal é considerado portador de infecção do trato urinário (ITU) associada ou não à DTUIF (BARSANTI et al., 2004).

A ITU é pouco diagnosticada em felinos jovens, sendo mais freqüente em gatos de meia-idade e idosos podendo desenvolver-se mais comumente de forma iatrogênica, secundária à urolitíase, defeitos anatômicos ou neoplasias (GUNNMOORE, 2003; CORGOZINHO et al., 2007). Outras condições como insuficiência renal crônica (IRC), diabete melitos (DM), uretrostomia e obstrução uretral podem proporcionar o desenvolvimento de ITU (RECHE Jr., 2005).

A contaminação ascendente por microorganismos normalmente encontrados no prepúcio, vagina e região perineal, e também de forma iatrogênica por cateterizações uretrais são as possíveis formas de contaminação do trato inferior, sendo a de maior incidência as obstruções uretrais, principalmente nos casos recidivantes com cateterizações anteriores para reestabelecimento do fluxo uretral 
(RECHE Jr. et al., 1998; BARSANTI et al., 2004; RECHE Jr., 2005; CORGOZINHO et al., 2007).

Os agentes mais comuns em ITU são bactérias aeróbias, principalmente Escherichia coli (E.coli), Proteus spp, Staphylococcus spp., Streptococcus spp., Pasteurella spp., Klebsiella spp., Pseudomonas spp., e Enterobacter spp (Reche Jr. et al., 1998). Segundo Litster et al. $(2007,2008)$ as bactérias mais comumente isoladas em gatos com ITU são E. coli,, Enterococcus faecalis e Staphylococcus felis. Em estudo prospectivo de gatos com doenças do trato urinário inferior, apenas $8 \%$ deles apresentaram crescimento bacteriano na cultura de urina. No entanto, todos esses animais haviam sido submetidos à sondagem uretral prévia para desobstrução, o que fatalmente poderia ter propiciado a instalação e proliferação dos agentes infecciosos (RECHE Jr. et al., 1998). Eggertsdóttir et al. (2007) verificaram que $33 \%$ dos gatos da Noruega com DTUIF tinham bacteriúria que excedeu $103 \mathrm{UFC} / \mathrm{ml}$, e em 25\% desses gatos, a bacteriúria excedeu $104 \mathrm{UFC} / \mathrm{ml}$, sem diferença significativa quanto ao método de coleta para cultura, e sendo mais freqüente em fêmeas. Os autores relacionaram este alto índice com a possibilidade de infecção secundária ao comportamento de acasalamento, já que na Noruega, a maioria dos gatos tem acesso ao exterior das casas, que é intensificado em épocas de verão. Já no inverno, devido ao frio, os gatos limitam-se a ficar mais tempo dentro de casa e diminuir suas atividades, aumentando os riscos potenciais para o desenvolvimento de cistite idiopática.

A infecção do trato urinário de gatos por Mycoplasma e Ureaplasma já foi descrita como provável causa etiológica da DTUIF. No entanto, Houwers \& Van Dongen (2006) comprovaram por técnicas de PCR que essa não é a causa de DTUIF, pois obtiveram resultados negativos em $100 \%$ das amostras estudadas. $O$ Corynebacterium urealyticum, bactéria multi-antibiótico resistente, é um possível agente etiológico da ITU em gatos, porém incomum (CAVANA et al., 2008).

A ITU também pode levar à formação de urólitos de estruvita, devido à contaminação por bactérias produtoras de urease, que aumentam a concentração de amônia e fosfato, elevando o pH urinário (BARSANTI et al., 2004). Porém sua participação na alcalizinação da urina não parece ter contribuição significativa (RECHE Jr. et al., 1998).

Embora raro, é crescente o número de relatos de infecção fúngica do trato urinário por Aspergillus nidulans nos gatos domésticos. Deve-se suspeitar dessa 
afecção quando a doença do trato urinário persiste e não responde aos diferentes tipos de tratamento. O diagnóstico necessita de cultura fúngica da urina obtida por cistocentese (ADAMAMA-MORAITOU et al., 2001).

\subsubsection{DTUIF X Cistite Intersticial Humana}

Uma provável semelhança entre a doença do trato urinário inferior dos felinos (DTUIF) e a cistite intersticial (CI) humana foi proposta devido às manifestações clínicas se caracterizarem exclusivamente por inflamação das vias urinárias inferiores, levando aos sinais clínicos observados como hematúria, disúria e polaquiúria, sem definição do agente causal. O termo cistite intersticial felina (CIF) deve ser aplicado àqueles pacientes que comprovadamente apresentarem características clínicas, laboratoriais e cistoscópicas semelhantes à doença urinária humana (RECHE Jr., 2003).

Existem diversas teorias propostas para explicar a inflamação vesical na cistite intersticial nos gatos e nos seres humanos, que incluem as infecções virais, a mastocitose vesical e o defeito na camada superficial da mucosa urinária de glicosaminoglicanos. Há evidências de que a inflamação vesical nesses casos seja de origem neurogênica, mediadas por neurotransmissores liberados de fibras aferentes e/ou eferentes (RECHE Jr., 2003), e com provável participação do sistema nervoso autonômico-simpático na patogenia tanto da DTUIF como da $\mathrm{Cl}$ nos humanos (RECHE Jr. \& HAGIWARA, 2004; WESTROPP, 2007).

Isto se tornou mais evidente quando da constatação de pacientes com $\mathrm{Cl}$ apresentando grande número de fibras nervosas sensoriais (fibras $\mathrm{C}$ ) contendo a substância P (SP) na lâmina própria da bexiga, e que estas se dispõem junto aos mastócitos. As terminações nervosas podem ser estimuladas em resposta à ação central como o estresse, ou por meio de compostos na urina como pH ácido, potássio, magnésio e cálcio, visto que há diminuição da camada protetora de glicosaminoglicanos, levando à liberação de neuropeptídeos (substância P) que pode resultar em maior recrutamento de fibras $\mathrm{C}$ e intensificação da doença. Esta intensificação ocorre devido ao aumento da vasculatura intramural, aumento da permeabilidade vascular e da parede vesical, edema de submucosa, contração da musculatura lisa, dor e degranulação de mastócitos, o que por sua vez pode 
exacerbar ainda mais os efeitos das fibras C (GUNN-MOORE, 2003; HOSTUTLER et al., 2005).

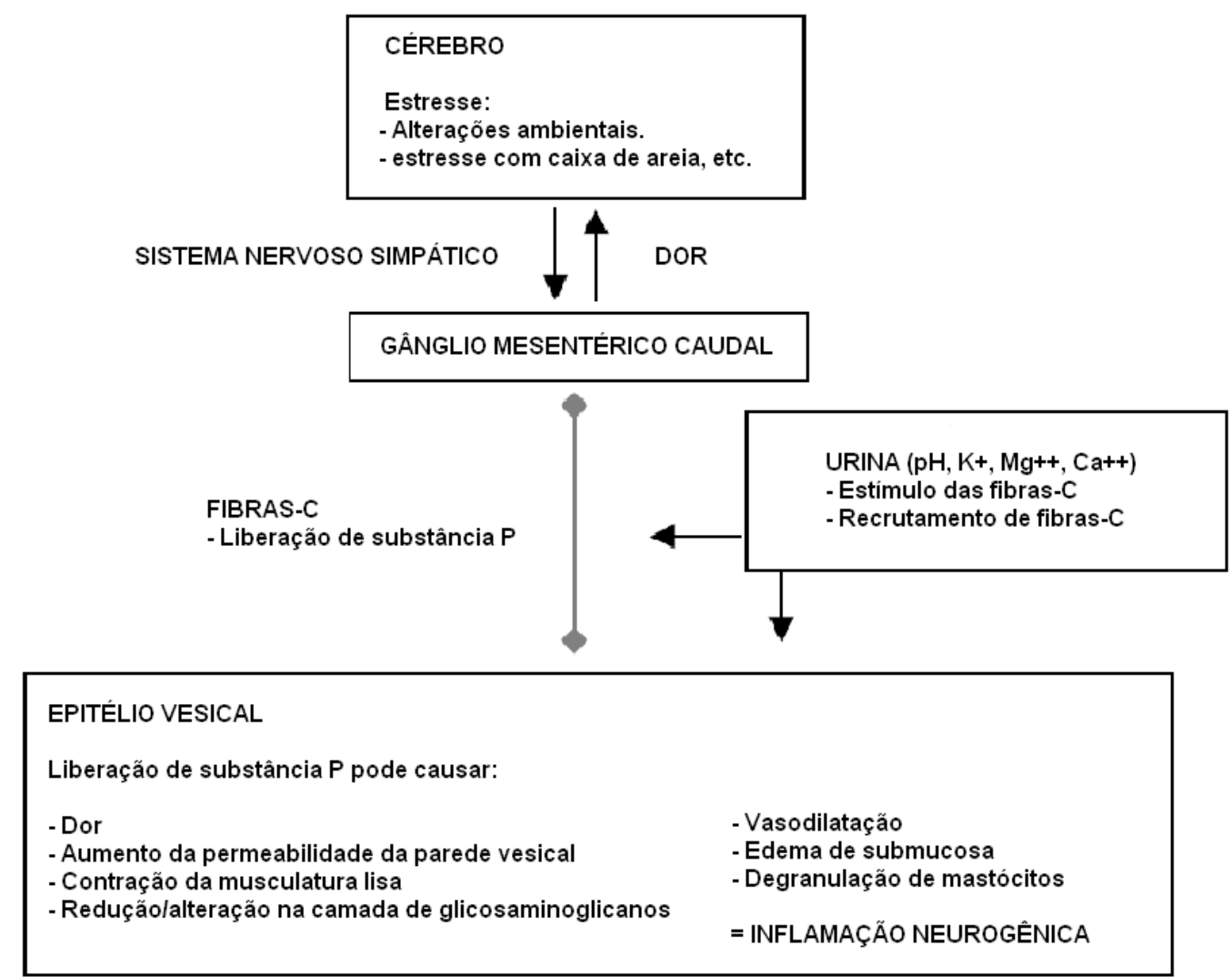

Figura 6 - Hipótese corrente da inflamação neurogênica da bexiga na cistite idiopática felina. (Adaptado de Gunn-Moore, 2003).

Os glicosaminoglicanos (GAGs), macromoléculas extracelulares de natureza mucopolissacarídica, estão presentes em todo o organismo e são excretados normalmente na urina. Os principais GAGs incluem o ácido hialurônico, a heparina, os sulfatos de condroitina A e C, de queratana, heparana e dermatana. Os GAGs têm a propriedade de atrair íons sódio e, conseqüentemente, moléculas de água, dando origem a uma camada de gel (ALBERTS et al., 1997). Segundo Hurst et al. (1996) e Parsons et al. (1990), essa camada pode ter papel importante para manter a impermeabilidade do epitélio vesical às moléculas presentes na urina. A penetração de substâncias, em decorrência de defeitos na camada de gel protetora, poderia causar lesão tecidual e liberação local de neurotransmissores e mediadores inflamatórios (PARSONS et al., 1990). A diminuição qualitativa e quantitativa da 
camada das glicosaminoglicanas é considerada um achado freqüente entre os pacientes humanos com $\mathrm{Cl}$ e gatos com DTUIF. A permeabilidade epitelial da bexiga de gatos com DTUIF foi recentemente avaliada por meio da administração intravesical de salicilato de sódio, com posterior mensuração dos níveis do fármaco na corrente sangüínea. Observou-se que a concentração plasmática do salicilato foi sete a oito vezes maior do que a observada em gatos normais (GAO et al., 1994)

Sugere-se uma possível inter-relação entre substância $P$, mastócitos e a patogenia da Cl. Gatos com Cl possuem aumento na densidade de fibras nervosas sensoriais contendo a substância $\mathrm{P}$, assim como aumento significativo na concentração dos receptores NK-2 para substância $P$, além de maior número de fibras eferentes catecolaminérgicas na bexiga, da mesma forma que em humanos (RECHE Jr., 2003).

Sabe-se que as atividades periféricas do sistema nervoso simpático (SNS) são controladas centralmente pelo complexo lócus coeruleus (LC) e pelo núcleo paraventricular (PVN), localizados, respectivamente, na ponte e no hipotálamo. A noradrenalina (NA) é o principal neurotransmissor, produzido e liberado pelas células que compõem o LC, e o hormônio liberador de corticotrofina $(\mathrm{CRH})$ o principal componente do núcleo PVN (ELAM et al., 1986).

Tem-se demonstrado que o estresse agudo e o crônico aumentam a imunorreatividade da tirosina hidroxilase (IR-TH), enzima limitante da taxa da síntese de catecolaminas, nos neurônios adrenérgicos do complexo LC de animais saudáveis (ZIGMOND et al., 1995). Pouco se sabe sobre os efeitos do estresse induzido por enfermidades crônicas, de ocorrência natural, nos neurônios NA-LC, como é o caso da DTUIF e da Cl.

A avaliação imunohistoquímica do complexo lócus coeruleus (LC) de gatos com DTUIF, na fase quiescente ou assintomática da doença demonstrou um aumento bastante significante da imunorreatividade para a enzima tirosina hidroxilase (TH-IR). Tal achado, segundo os autores do referido estudo, poderia sugerir a existência de uma população de felinos que apresentam uma hiperatividade do sistema nervoso simpático (SNS) e que, aliada a outros fatores predisponentes, poderia determinar o aparecimento, ou mesmo o agravamento dos sinais clínicos da doença urinária felina (RECHE Jr. \& BUFFINGTON, 1998).

Os fármacos antidepressivos, como a amitriptilina, por diferentes mecanismos de ação, promovem diminuição na atividade das células do complexo lócus 
coeruleus, que é responsável pelo estímulo excitatório da bexiga, levando a diminuição dos níveis de noradrenalina circulante no sistema nervoso central (SNC). Portanto, conclui-se que as células noradrenérgicas do complexo lócus coeruleus devem ter participação importante na perpetuação ou mesmo exacerbação dos sinais clínicos observados em gatos com DTUIF (RECHE Jr. \& HAGIWARA, 2004; HOSTUTLER et al., 2005).

Contudo, ainda está indefinida a real participação das fibras nervosas sensoriais e eferentes que se encontram em maior número tanto na bexiga de gatos quanto em pessoas com $\mathrm{Cl}$, e é preciso avaliar se essa neuroplasticidade vesical seria a causa ou a conseqüência da inflamação (RECHE Jr., 2003).

O agravamento dos sintomas das doenças urinárias em situações de estresse como mudança brusca no manejo ambiental, viagens, introdução de novos animais ou novos moradores, participação em exposições e até mesmo alterações climáticas, é um forte indício do envolvimento do sistema nervoso simpático na patogenia da CI (RECHE Jr., 2003; RECHE Jr. \& HAGIWARA, 2004).

Reche Jr. et al. (1998) evidenciaram espessamento da parede vesical e irregularidade da mucosa da bexiga em felinos sadios (mas que já haviam desenvolvido DTUIF há algum tempo), por meio de técnicas radiográficas. Porém, estas alterações podem ocorrer devido à ação irritante de cristais e agregados de cristais, pela obstrução uretral que leva ao aumento da pressão intravesical provocando hipertrofia ou hiperplasia da camada muscular, ou ser devida à inflamação vesical neurogênica como em mulheres com $\mathrm{Cl}$. Esse espessamento da parede vesical foi comprovado por estudos histopatológicos e morfométricos da bexiga de gatos com histórico de DTUIF recidivante. Os animais participantes deste estudo não apresentavam sinais de doença urinária há pelo menos três meses, portanto pode-se considerar que o espessamento da parede da bexiga não seja secundário à obstrução e ao esforço para micção como proposto anteriormente. $O$ espessamento da parede vesical não variou significativamente com relação a diferentes regiões anatômicas da bexiga. Dessa forma, o processo inflamatório vesical observado nos felinos com DTUIF e sem manifestações clínicas da doença é de caráter crônico e inespecífico (RECHE Jr. \& HAGIWARA, 2001).

A prevalência de cristalúria em gatos com cistite intersticial não difere significativamente dos gatos não afetados (KRUGER \& OSBORNE, 2009), e sabese que a cristalúria não está envolvida na etiologia da cistite idiopática, pois mais de 
$50 \%$ dos gatos afetados não tem nenhum tipo de cristal na urina (KRUGER et al., 2008).

\subsubsection{Defeitos Congênitos}

Os remanescentes do úraco são comuns e assintomáticos nos felinos, embora tenham sido identificados em gatos com sinais DTUIF. O divertículo vesicouracal (DVU) consiste em anomalia de caráter congênito, cuja alteração provavelmente se desenvolveu antes ou logo após o nascimento, persistindo indefinidamente (OSBORNE et al., 2000). Ocorre quando uma porção do úraco localizado no vértice da bexiga falha ao fechar (WALDRON, 1998). O resultado é um divertículo cego com variações de tamanho, que se projeta do vértice da bexiga (Figura 8). Esse tipo de anomalia tem sido associado ao aumento da resistência na saída da urina através da uretra. Em felinos, ao contrário do que ocorre nos cães, nem sempre tem significado clínico, sendo detectados com certa freqüência quando há disfunção do trato urinário inferior, principalmente, a obstrução uretral (OSBORNE, 1989; WALDRON, 1998).

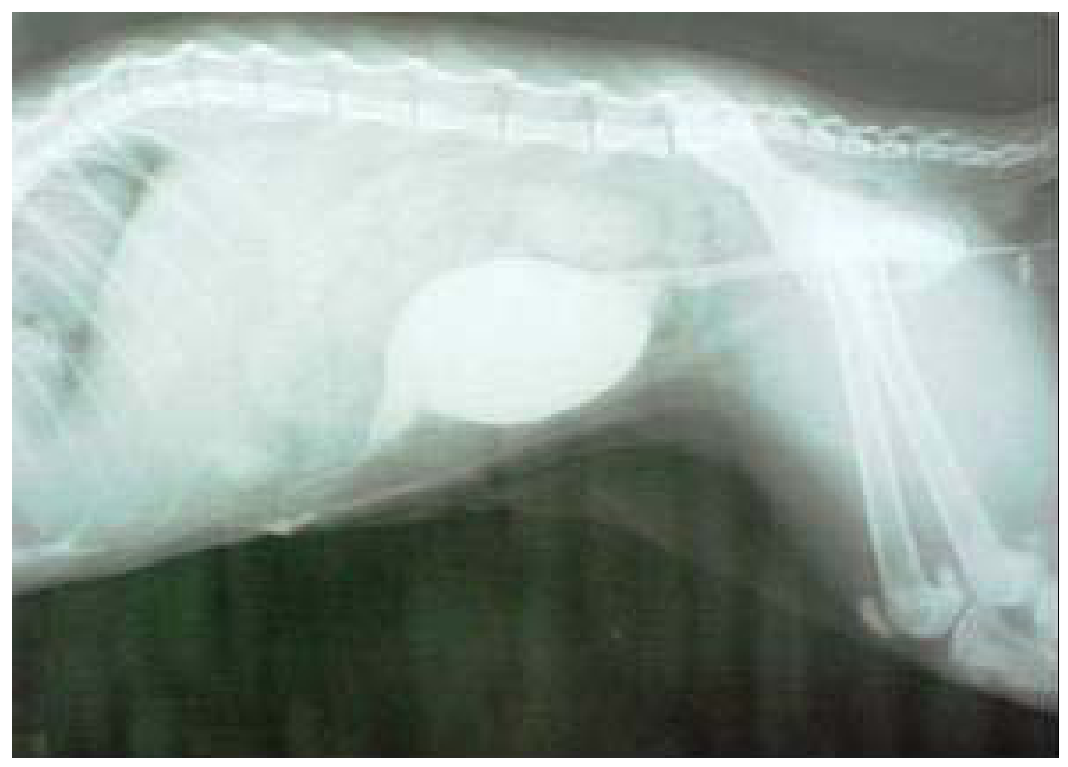

Figura 7 - Persistência do úraco em felino diagnosticado através de cistografia. (Adaptado de Aleixo et al. 2007).

Alguns fatores que podem alterar o tamanho do divertículo incluem o tamanho e grau de patência do ducto vesiculo-uracal remanescente na parede vesical, a 
duração da hiperdistensão vesical e a magnitude de necrose e inflamação da bexiga. $O$ fato de o divertículo ser maior em gatos que apresentaram obstrução uretral do que os que nunca sofreram obstrução reforça a hipótese de que a hiperdistensão vesical influencia a formação de divertículo do úraco (OSBORNE et al., 1987). Mesmo não havendo diferenciação se eram primários (congênitos) ou secundários ao aumento de pressão intravesical, a maioria dos divertículos vesicouracais são resultado, e não causa de cistite idiopática (KRUGER et al., 2008).

Geralmente, os animais não apresentam sinais clínicos, porém eles podem ocorrer associados a sinais característicos do trato urinário inferior (hematúria, poliúria, disúria e polaquiúria). O diagnóstico é confirmado por cistografia com contraste positivo ou duplo contraste. O tratamento recomendado é cirúrgico (OSBORNE et al., 1991).

\subsubsection{Neoplasias}

Neoplasias vesicais são incomuns nos gatos, quando comparados com cães e humanos, e geralmente acometem pacientes idosos (acima de 10 anos). A neoplasia vesical mais comum é o carcinoma de células de transição, seguido por adenocarcinoma, leiomioma e outros tumores epiteliais malignos, sarcomas, tumores benignos e linfoma. O carcinoma de células de transição pode ser primário ou secundário à inflamação crônica da bexiga (GUNN-MOORE, 2003; BARSANTI et al., 2004; FORRESTER, 2007a).

\subsubsection{Trauma}

Contusões ou rupturas podem ocorrer devido a trauma do trato urinário inferior. A ruptura vesical é a injúria mais comumente diagnosticada, e pode ocorrer secundária a atropelamentos, perfurações por projéteis ou fragmentos ósseos devido à fratura pélvica, palpação excessiva de bexiga hiperdistendida e cateterização imprópria. Ruptura uretral também pode ocorrer, porém menos freqüente que a ruptura da bexiga (BARSANTI et al., 2004). 


\subsubsection{Virais}

Não há nenhuma comprovação de que infecções virais provoquem doença do trato urinário inferior de ocorrência natural, embora alguns estudos ainda sejam realizados para avaliar a possível participação do calicivírus felino na patogenia da cistite idiopática felina (BARSANTI et al., 2004; KRUGER et al., 2008).

\subsection{Sinais Clínicos}

O histórico e sinais clínicos dependem da duração da doença e do grau da obstrução, quando esta ocorrer. Os primeiros sinais clínicos observados em um felino com DTUIF são polaquiúria, disúria/estrangúria, hematúria (Figura 9) e a possível obstrução uretral parcial ou completa, que pode ser observada quando o animal demonstra repetidas tentativas de micção, dentro da vasilha sanitária ou até em lugares inapropriados da casa, com a emissão de pouca urina, saindo na maioria das vezes apenas gotículas de coloração avermelhada (MARKWELL et al., 1998). Entre os inúmeros episódios, o gato vocaliza devido ao desconforto e lambe incessantemente a genitália e/ou o abdômen (HURLEY, 1998).

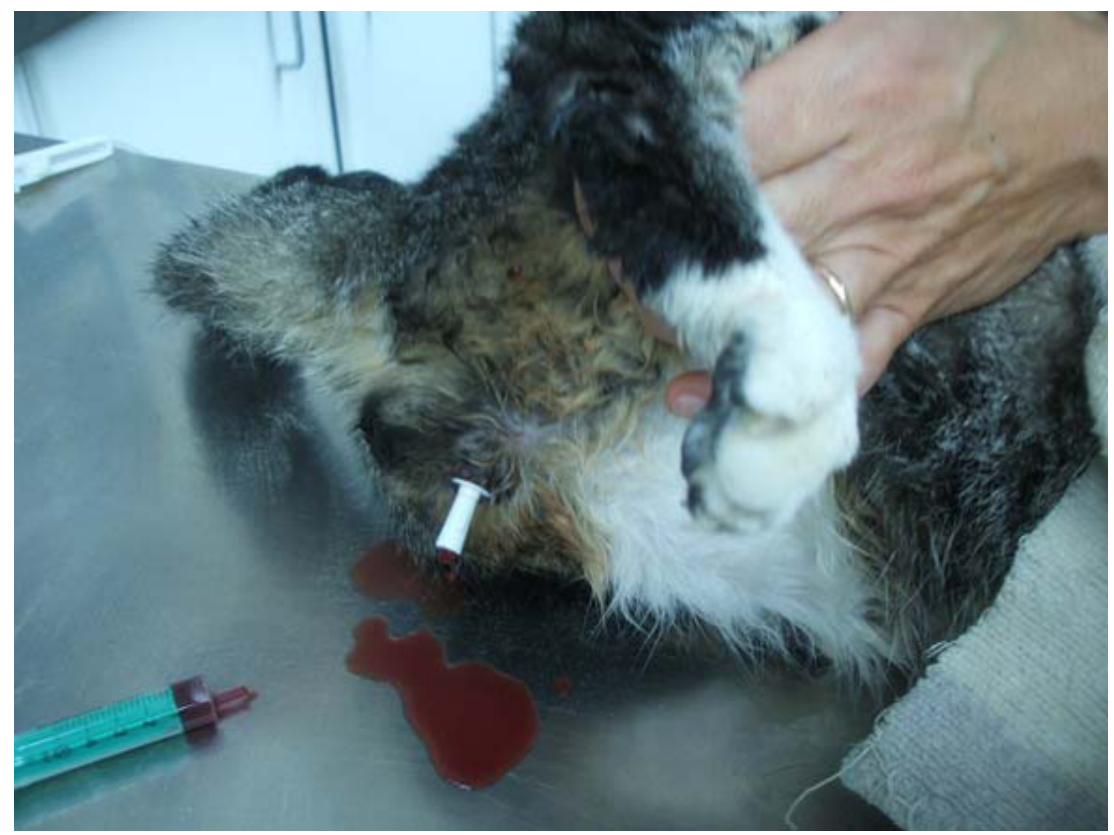

Figura 8 - Felino macho apresentando hematúria, após cateterização urinária. (Adaptado de Pinheiro, 2009). 
Infelizmente, na maioria das vezes ocorre uma demora por parte do proprietário para perceber as alterações comportamentais do animal, levando ao Médico Veterinário após 24 a 36 horas que o felino está obstruído, possivelmente já com sintomas de azotemia pós renal, incluindo anorexia, apatia, emese e hipotermia, que podem levar o animal ao colapso. Se o quadro não for revertido, o óbito pode ocorrer em 3 a 6 dias (BARTGES et al.,1996).

Durante o exame clínico, observa-se o pênis hiperêmico e edemaciado, podendo se apresentar protraído e com presença de partículas semelhantes a grãos de areia ao redor do órgão (SOUZA, 2003). Pode apresentar escoriações e sangramento devido à lambedura incessante do gato (GRAUER, 1994).

$\mathrm{Na}$ palpação, nota-se vesícula urinária distendida, podendo ou não haver micção no momento da palpação. Isso se deve à obstrução luminal ser parcial ou total, sendo na última, mais dolorosa. Nos gatos não obstruídos, a palpação suave da bexiga pode desencadear a micção. Devido à fragilidade da musculatura, a pressão exercida sobre a bexiga deve ser cautelosa para não ocasionar ruptura (COWAN, 1998).

\subsubsection{Complicações}

Com a obstrução uretral, a bexiga se dilata além da sua capacidade, ocasionando um aumento da pressão intravesical, fazendo com que a urina retida ascenda novamente aos rins. Com esse movimento retrógrado a urina promove um aumento da pressão intratubular, mais especificamente sobre a cápsula de Bownman. O organismo tenta compensar esse aumento de pressão promovendo vasodilatação da artéria aferente, com a liberação de prostaglandina. Tal mecanismo acarreta aumento do fluxo renal, o que eleva a pressão intraglomerular, compensando a alta pressão da cápsula e mantendo a taxa de filtração glomerular aceitável por algumas horas (BARTGES \& FINCO, 1996).

Após 24 horas há vasoconstrição arteriolar, que causa acentuada queda da taxa de filtração glomerular. Acredita-se que essa vasocontrição esteja relacionada com o infiltrado inflamatório que ocorre nos rins. Logo após a obstrução há uma infiltração de leucócitos, principalmente linfócitos, nos túbulos distais. Esses linfócitos, assim como os macrófagos são responsáveis pela liberação de tromboxano A2 e ativação do sistema renina-angiotensina que tem como principal 
conseqüência, a vasoconstrição. $O$ aumento gradativo da pressão da cápsula de Bowman pela produção, mesmo que pequena de urina, acaba superando a pressão da artéria aferente, devido à vasoconstrição, ocasionando com isso a interrupção completa da filtração glomerular, que compromete a capacidade de concentração tubular, além de outras funções tubulares, entre elas, a regulação do sódio e a capacidade de reabsorção de água, e ainda prejudica a excreção de ácidos e potássio, resultando em uremia, acidose metabólica e hipercalemia (LANE, 2009) levando os rins à falência renal aguda (FRA).

A FRA é definida como a súbita incapacidade dos rins em desempenhar adequadamente suas funções (THOMAS, 2000). Pode ter causas pré-renais, renais e pós-renais, sendo a obstrução uretral secundária a DTUIF um exemplo de causa pós-renal. Na FRA a principal causa mortis nos felinos é a hipercalemia (HUEB \& KALAÁS, 1997).

O potássio é o cátion predominante no meio intracelular, sendo que $90 \%$ de sua concentração é excretada pelos rins (LUNA, 2002). Os sintomas da hipercalemia constatam-se predominantemente no sistema cardiovascular. Com sua progressão, manifestam-se também sinais no sistema muscular, com fraqueza, e no sistema gastrintestinal, com náuseas, emese, diarreia e dor abdominal (CARMONA \& MENDONÇA, 2002). O excesso de potássio extracelular diminui o potencial de repouso das membranas celulares, produzindo efeito de bloqueio despolarizante. Com isso, ocorre alteração da propagação do impulso elétrico nas células cardíacas (SCHAER, 1977).

O magnésio, o segundo íon mais comum do líquido intracelular, também aumenta na FRA obstrutiva. A hipermagnesemia pode ser assintomática (HUEB \& KALAÁS, 1997) ou pode piorar os efeitos cardíacos da hipercalemia, como a bradicardia, aumento do intervalo $\mathrm{P}-\mathrm{R}$ e causar graus variáveis de bloqueio átrioventricular (BAV) (SANCHES \& MOFFA, 2001), além de ocasionar depressão do sistema nervoso central e fraqueza muscular (CARMONA \& MENDONÇA, 2002).

Alguns felinos apresentam depressão do sistema nervoso central levando a depressão de consciência, resultante da diminuição da perfusão no tecido nervoso, uremia e da acidose metabólica (FINCO \& CORNELIUS, 1977). Graus variados de flacidez, fraqueza e paralisia muscular ocorrem como resultado do impedimento da transmissão do impulso nervoso. A avaliação da resposta ao estímulo do 
pinçamento da cauda e a inspeção da tonicidade do esfíncter anal são importantes para a detecção de déficits neurológicos concomitantes (HOLT, 1998).

Mesmo com alívio do bloqueio uretral, a lesão tubular continua durante algum tempo, presumivelmente até solucionar-se o desequilíbrio hidroeletrolítico e ácidobásico. O dano tubular ou perda de néfrons durante o processo contribui para a poliúria acentuada, observada após o restabelecimento do fluxo urinário normal (LANE, 2009).

Além disso, esses pacientes podem apresentar sinais cardiovasculares, como arritmia cardíaca, resultante de distúrbios hidroeletróliticos, incluindo a desidratação, acidose metabólica e principalmente a hipercalemia (acima de $7 \mathrm{mEq} / \mathrm{L}$ ). Gatos gravemente hipercalêmicos, com níveis séricos de potássio de 9 a $10 \mathrm{mEq} / \mathrm{L}$ se apresentam bradicárdicos (PERKOWISK, 2007). A hipercalemia induz arritmias cardíacas por distúrbios de condução supraventricular que podem ser observadas pela eletrocardiografia (CARTER et al., 1993).

A acidose metabólica também pode resultar em alterações pulmonares. A compensação respiratória ocorre pelo aumento da respiração por minuto por meio do aumento na freqüência respiratória $(F R)$, isto é taquipneia, ou devido ao aumento na profundidade de cada volume inspirado. A FR será maior na fase inicial e após esse período, o animal progride para bradipneia (SCHAER, 1975).

Outras complicações pouco comuns da DTUIF, decorrentes de obstrução uretral, incluem a pielonefrite, hidronefrose, necrose tubular, cistite crônica, anemia e gastropatia urêmica devido à azotemia (WOUTERS et al., 1998).

\subsection{Diagnóstico}

O diagnóstico pode ser obtido pelo histórico clínico e exame físico do paciente, além de exames complementares auxiliares, como exames radiográficos (simples ou cistografia com duplo contraste), ultrassonográficos e cistoscopia, e ainda os exames laboratoriais como urinálise, cultura, antibiograma, hemograma e dosagem de enzimas bioquímicas (BARSANTI et al., 2004).

A anamnese completa é importante para determinar a presença dos sinais clínicos, identificar fatores ambientais que contribuam para o estabelecimento da doença e traçar os possíveis diagnósticos da DTUIF. Além disso, deve realizar-se 
sempre um exame físico minucioso do trato urinário inferior e da região perineal circundante (WESTROPP, 2007). Ao exame clínico, um gato com DTUIF sem obstrução encontra-se aparentemente sadio, com a bexiga pequena e fácil de ser esvaziada por compressão. Em contrapartida, o achado de maior relevância durante o exame clínico do gato com obstrução é a presença da bexiga repleta e distendida, sendo difícil ou impossível de ser esvaziada por compressão (GRAUER, 2003).

Porém para se confirmar o diagnóstico e avaliar a extensão do processo devem-se realizar exames laboratoriais e, caso necessário diagnóstico por imagem.

\subsubsection{Diagnóstico por Imagem}

A radiografia abdominal simples pode constituir-se em instrumento diagnóstico muito útil. É recomendado aplicar enema de água morna antes do exame radiológico para conseguir avaliar completamente a uretra (WESTROPP, 2007). Em algumas situações, a cistografia contrastada é efetiva na identificação de pequenos cálculos, cálculos radioluscentes, ruptura uretral ou vesical, estenose uretral, divertículo uracal, neoplasias e processos inflamatórios (HOLT,1998).

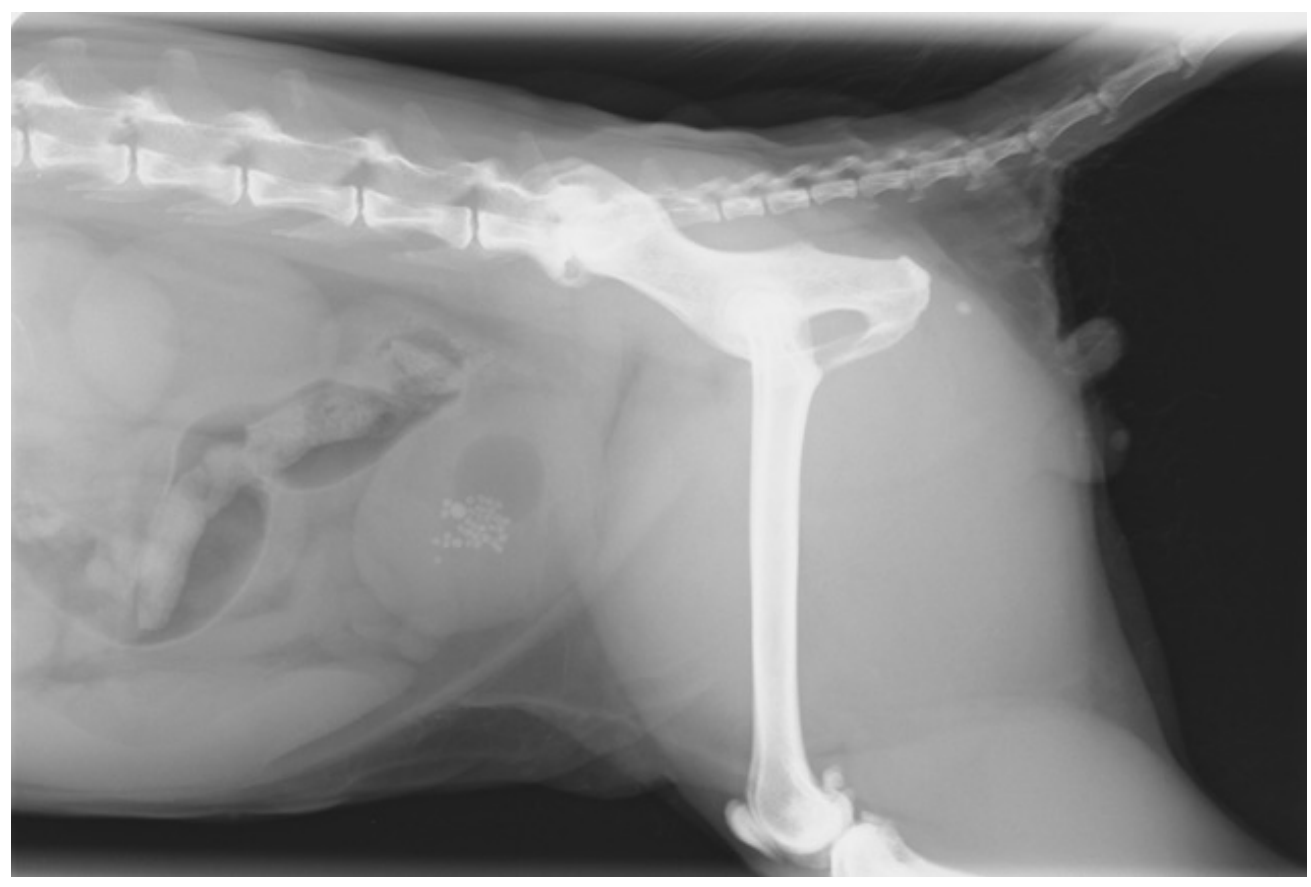

Figura 9 - Evidência radiográfica de cálculos na bexiga e na uretra distal de felino obstruído. (Adaptado de Pinheiro, 2009). 
A avaliação ultrassonográfica dos gatos obstruídos tem a vantagem de analisar a integridade do trato urinário superior e inferior, além de verificar a presença de tampões (mucoproteínas e/ou cristais, coágulos, debris) e urólitos na vesícula urinária que possam migrar para uretra, e dessa forma perpetuar a obstrução intramural, como também, observar a presença de neoplasias e anomalias anatômicas. Contudo, o trajeto da uretra não é totalmente visualizado devido à interferência do púbis (HURLEY,1998).

Se o gato apresentar episódios recorrentes de DTUIF e já tiverem sido efetuados os exames de imagem mencionados acima, poderá ser considerada a realização da cistoscopia. O exame cistoscópico ou uroendoscópico do trato urinário inferior dos felinos é utilizado para visualização da uretra e bexiga em baixas e altas pressões, o que facilita a detecção de pequenos cálculos císticos, divertículos, uretéres ectópicos e pequenos pólipos. É possível também avaliar o grau de intensidade do edema, de glomerulações, da friabilidade e de fibroses. Caso o cenário cistoscópico indique, poderá ser realizada a biopsia da bexiga para análise histopatológica e ocasionalmente cultura (WESTROPP, 2007). As informações obtidas no exame cistoscópico são complementares e devem ser associadas com achados de radiografias e ultrassonografias. As técnicas mais utilizadas são a trans uretral (fêmeas e machos penectomizados) e a pré-púbica (machos). Para a realização do procedimento há necessidade de anestesia geral e assepsia de toda a região perineal, além de ter conhecimento e treinamento da técnica para otimizar os resultados da cistoscopia (RECHE Jr., 2003).

\subsubsection{Exames Laboratoriais}

Os achados laboratoriais mais comuns incluem: discreta hiponatremia, hipercalemia, hipermagnesemia, hiperfosfatemia, hiperglicemia, hiperproteinemia, hipocalcemia, hipocloremia e azotemia pós-renal. Marcadores séricos da função renal, como a uréia e a creatinina, estão indicados para avaliar os animais com obstrução uretral, que podem estar azotêmicos. Pela gasometria se verifica acidose metabólica. Atualmente, tem sido indicada também a mensuração da enzima urinária N-Acetil-ß-D-glucosaminidase (NAG) como marcador precoce de disfunções renais, indicando lesão renal antes mesmo do aumento das concentrações séricas de uréia e creatinina. Na maioria dos felinos com doença do trato urinário inferior 
não obstrutiva, esses valores estão normais devido à ausência de lesões no parênquima renal (SATO et al., 2002).

A urinálise irá proporcionar informações importantes tais como pH urinário, o grau de hematúria, densidade urinária, proteinúria e a presença ou não de células inflamatórias, bactérias e cristais (BARSANTI et al., 1994). O exame de urina em felinos obstruídos demonstra intensa hematúria principalmente pela distensão da vesícula urinária com ruptura de vasos e hemorragia além do processo inflamatório. O pH urinário deve ser avaliado 4 a 6 horas após a refeição, pois se a urina estiver ácida, provavelmente será ácida ao longo do dia (OSBORNE et al.,1989). A cultura de urina deve ser feita quando a urinálise indicar piúria e/ ou bacteriúria além de hematúria, sendo indicada a coleta por cistocentese nestes casos (SOUZA, 2003).

A análise da urina é feita de forma quantitativa e qualitativa (SOUZA, 2003). A infecção bacteriana está presente quando o número de bactérias exceder 1000 unidades formadoras de colônias por mililitro na amostra colhida pela cateterização ou quando houver qualquer crescimento na amostra obtida pela cistocentese (TUZIO, 2001). A infecção por bactérias produtoras de urease, especialmente Staphylococcus sp. e Proteus sp. pode favorecer a formação de urólitos de fosfato amoníaco magnesiano (OSBORNE et al.,1989).

A densidade da urina deve ser cuidadosamente analisada, sobretudo em felinos mais velhos, de modo a verificar a existência de concentração adequada. $A$ dieta também é importante para a densidade urinária final, pois gatos submetidos à dieta seca, possuem geralmente densidade entre 1040 a 1060. Animais que comem ração úmida provavelmente terão valores próximos a 1030 (WESTROPP, 2007).

A análise do urólito colhido é fundamental para detectar sua composição com o intuito de selecionar protocolos terapêuticos que promovam a dissolução e prevenção dos mesmos (BUFFINGTON \& CHEW,1999).

Análises histopatológicas de gatos com DTUIF são bastante semelhantes às dos humanos com cistite intersticial, apresentando pronunciado edema da lâmina própria, infiltrado celular mononuclear, aumento do número de mastócitos na mucosa vesical, epitélio pregueado e hiperplásico, petéquias subepiteliais, infiltrado inflamatório perineural e aumento no número de vasos sanguíneos em lâmina própria. As petéquias ou hemorragias subepiteliais, assim como todo o processo inflamatório, alterações histológicas e sinais clínicos podem ser atribuídas à importante participação dos mastócitos na etiopatogenia da CIF, com conseqüente 
liberação de substâncias como a histamina, heparina, proteases, fosfolipases, citoquinas, leucotrienos, prostaglandina, fator de necrose tumoral (FNT) e polipeptídeos vasoativos (RECHE Jr. \& HAGIWARA, 2001; RECHE Jr., 2003). Contudo, esses achados são típicos, mas não patognomônicos da CIF (HOSTUTLER et al., 2005).

À necropsia de animais com histórico de DTUIF, observa-se a bexiga distendida com a parede acentuadamente avermelhada com conteúdo sanguinolento e muitas vezes contendo ou não coágulos. Em alguns casos, a mucosa vesical apresenta-se ulcerada e recoberta por fibrina, e há edema perirrenal com infiltração de líquido translúcido. As alterações nos rins e uretéres são raras podendo haver presença de hidronefrose e hidrouretér em grau discreto a moderado, além de gastropatia urêmica, odor amoniacal e anemia (WOUTERS et al., 1998).

\subsection{Propostas Terapêuticas}

A chave para o sucesso no tratamento é o diagnóstico correto. A identificação da causa específica possibilita a adoção do tratamento adequado. Quando nenhuma causa subjacente puder ser identificada, o paciente deverá ser tratado como portador de cistite idiopática felina (GUNN-MOORE, 2003).

Recomendações específicas para o manejo de gatos com cistite idiopática aguda e crônica não obstrutiva baseiam-se nos resultados de estudos controlados que documentem a eficácia e segurança de agentes terapêuticos. Devem seguir alguns passos como:

1. educar o cliente enfatizando o comportamento biológico da doença e a falta de estudos controlados demonstrando a eficácia das terapias propostas;

2. estratégias para minimizar a obstrução uretral;

3. considerar a utilização de medicamentos que possam reduzir a gravidade e duração dos sinais clínicos;

4. estratégias para minimizar o risco de recorrência;

5. prevenir doença iatrogênica (KRUGER \& OSBORNE, 2009).

Os objetivos do tratamento de felinos com obstrução uretral decorrente de cistite idiopática são a restauração da permeabilidade do lúmen uretral, e a correção 
das alterações sistêmicas com reposição de fluidos e eletrólitos (CORGOZINHO \& SOUZA, 2003; BARSANTI et al., 2004).

A seguir serão abordadas as diferentes formas terapêuticas utilizadas no manejo de gatos com DTUIF, independente da causa subjacente, podendo ser utilizadas isoladamente ou associadas, dependendo do diagnóstico e das condições individuais envolvidas.

\subsubsection{Protocolo Anestésico}

Antes de iniciar a restauração da permeabilidade do lúmen uretral do paciente é necessário sua contenção. Felinos altamente debilitados ou muito dóceis podem ser contidos fisicamente em combinação com anestesia tópica. As cateterizações da uretra realizadas sem a devida sedação podem acarretar em ruptura uretral com conseqüente extravazamento de urina para o tecido periuretral (SOUZA, 1998).

Os anestésicos são administrados cautelosamente, visto que as dosagens inferiores às recomendadas para pacientes com função renal normal são exigidas naqueles com azotemia pós-renal, o que vale principalmente para os fármacos excretados pelo rim. O cloridrato de quetamina é o anestésico dissociativo comumente utilizado em gatos, porém produz rigidez muscular o que dificulta a cateterização uretral. Dessa forma, têm sido empregada a associação do cloridrato de quetamina na dosagem de 1 a $2 \mathrm{mg} / \mathrm{kg}$, com o diazepam na dosagem de 0,2 $\mathrm{mg} / \mathrm{kg}$, por via intravenosa, para facilitar a inspeção e melhor relaxamento da musculatura da uretra. A quetamina é eliminada na forma ativa pelos rins, e deve ser administrada em baixas doses. Anestésicos voláteis halogenados e barbitúricos de curta ação podem também ser empregados (SOUZA, 2003).

Gatos não devem ser submetidos à anestesia induzida por máscara com halotano devido ao seu potencial arritmogênico, dando-se preferência a indução anestésica com isoflurano ou sevoflurano. A indução também pode ser feita com a utilização de propofol (2-5 mg/kg, IV) ou etomidato (1 mg/kg IV) lentamente e em doses baixas até que se produza o efeito desejado (GREEN \& GRAUER, 2007).

O propofol é um anestésico intravenoso de ultracurta duração, agindo por cerca de 5 a 10 minutos após a aplicação endovenosa, sendo ideal para a utilização em procedimentos curtos ou sedação. Possui ação vasodilatadora e necessita cautela no seu uso em animais hipovolêmicos ou com depressão cardiovascular, 
principalmente se for administrado em bolus. Apresenta biotransformação extrahepática em sítios como pulmão, rim e trato digestório. Apesar do propofol ser eliminado por via renal após ser convertido em metabólitos inativos, não foram notadas alterações clínicas em animais com insuficiência renal (PERKOWISK, 2007; CORRÊA, 2005). Por causa da formação de compostos fenólicos, a formação de metahemoglobinemia e corpúsculos de Heinz são notados em gatos que sofrem sucessivas aplicações desse fármaco, devendo ser utilizado com cautela em felinos anêmicos (GLOWASKI \& WETMORE, 1999).

O etomidato também é um anestésico de ultracurta duração (em torno de 5 a 10 minutos após ser aplicado). É muito utilizado em animais cardiopatas e pacientes instáveis hemodinamicamente, com mínimos efeitos cardiovasculares. Pode provocar vômito e mioclonias quando administrado isoladamente, o que pode ser minimizado quando combinado a opióides ou benzodiazepínicos no momento da aplicação. Por ser diluído em propilenoglicol, deve ser utilizado com cautela em animais com comprometimento renal, o que pode ser evitado diluindo-se o etomidato em solução salina antes da aplicação (PERKOWISK, 2007). A utilização de barbitúricos em animais azotêmicos deve ser evitada, pois na maioria das vezes, esses animais estão em estado de acidose metabólica, o que aumenta a fração livre desses anestésicos (GREEN \& GRAUER, 2007).

\subsubsection{Restabelecimento da Patência Uretral}

Nos casos mais graves, com presença de obstrução uretral por tempo suficiente para ter provocado alterações eletrolíticas e ácido-básicas, estas devem ser primeiramente corrigidas antes de realizar a desobstrução uretral, que necessita de sedação ou anestesia devido ao procedimento ser desconfortável e doloroso (RIESER, 2005). Fluidoterapia deve ser iniciada em todos os pacientes com sinais de azotemia pos-renal antes da tentativa de desobstruí-los. Não existe risco de ruptura da bexiga com a fluidoterapia. Deve-se administrar rapidamente solução fisiológica de Cloreto de Sódio a 0,9\% $(20-30 \mathrm{ml} / \mathrm{kg})$ e depois reavaliar o paciente. Após a estabilização do felino, inicia-se a desobstrução.

Para verificar a presença ou não de tampão uretral ou urólito, a inspeção da uretra peniana é essencial. Implica-se na retenção do prepúcio e na exposição do pênis, seguindo a seguinte ordem de prioridade para a desobstrução do felino: (1) 
massagem uretral distal, (2) tentativas de indução de micção pela suave palpação da bexiga, (3) cistocentese, quando houver insucesso nas etapas anteriores, (4) desobstrução do lúmen uretral por propulsão hídrica, (5) combinações de 1 a 4, (6) estudo radiográfico para determinar a causa da obstrução uretral, e (7) procedimentos cirúrgicos (CORGOZINHO \& SOUZA, 2003).

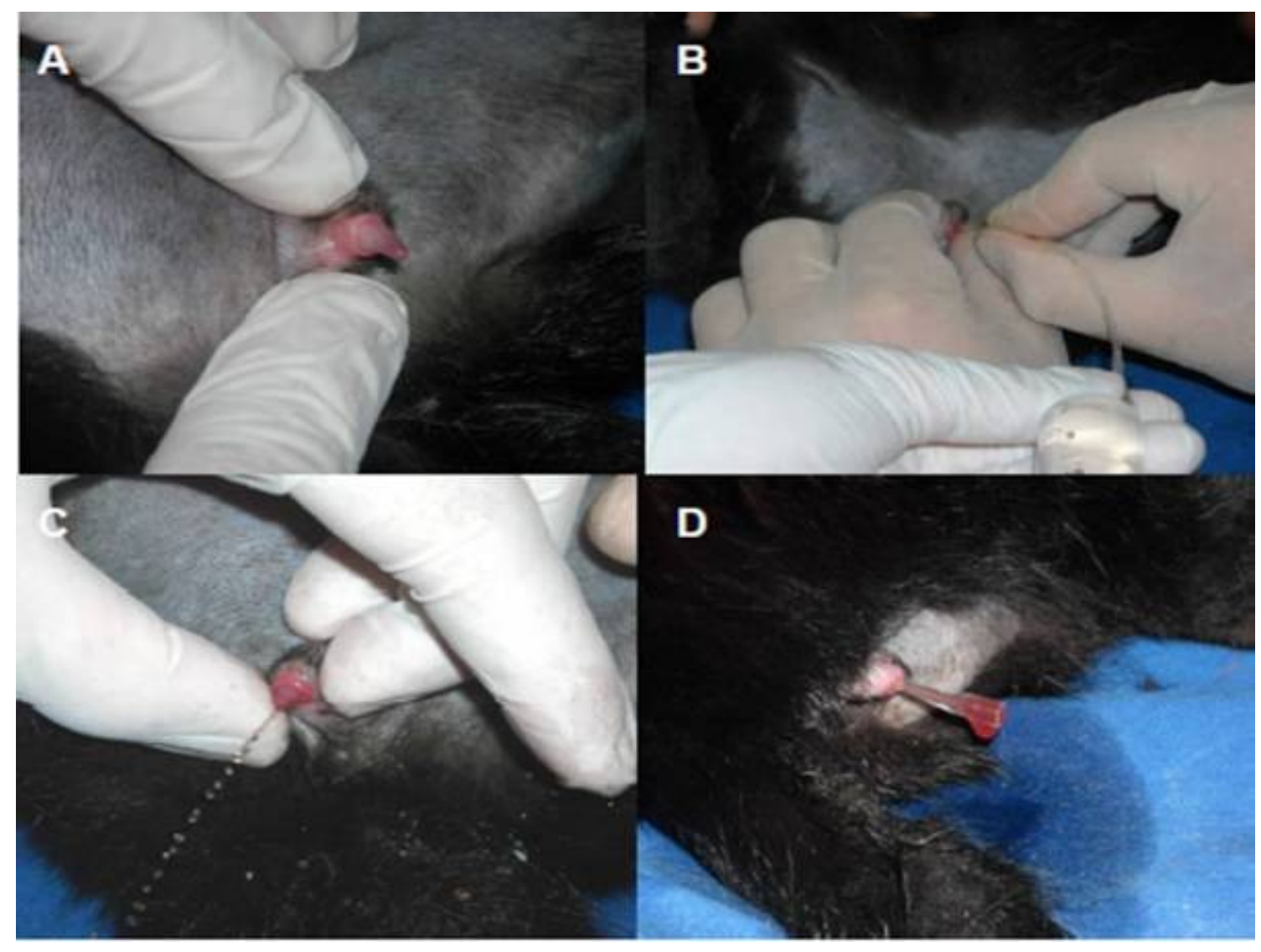

Figura 10 - Felino, macho, SRD, 2 anos e 6 meses, apresentando DITUIF obstrutiva. (A) Tricotomia ampla da região perineal (notar a inflamação na extremidade do pênis), (B) procedimento de desobstrução através de retrohidropropulsão com solução salina estéril e cateter urinário tom-catß̊. (C) Após a desobstrução com fluxo urinário normal, e (D) introdução do cateter urinário para lavagem vesical (notar a coloração hematúrica da urina através da sonda urinária em decorrência da injúria à perede vesical) (Adaptado de Felício, 2009). 
A descompressão da bexiga superdistendida, por meio da cistocentese pode facilitar a repulsão de tampões ou urólitos para o interior da vesícula urinária e diminuir a pressão intra-uretral, além de proporcionar uma amostra de urina não contaminada para cultura (MORAIS, 2004). Porém a cistocentese não é recomendada em casos de obstrução uretral prolongada, ou quando o paciente possuir o histórico de urina demasiadamente vermelha, pois isto sugere desvitalização tecidual da vesícula urinária, que com a introdução da agulha, pode resultar em ruptura de bexiga (LANE, 2009).

O próximo passo é a introdução da sonda no lúmen uretral até alcançar a oclusão mecânica (tampão, urólito ou coágulos). A porção proximal da sonda uretral deve ser arredondada, atraumática e lubrificada com lubrificante estéril. As sondas uretrais flexíveis ou cateteres uretrais de polipropileno são as preferidas para desobstrução uretral em gatos (SOUZA, 1998). O cateter tom cat $\AA^{\circledR}$ utilizado com maior eficácia na desobstrução uretral não deve ser deixado na bexiga.

Quantidades de solução salina estéril são impelidas sob pressão, deixando que ocorra o escoamento do líquido ao redor da sonda, promovendo uma pressão sobre o material obstrutor, forçando sua remoção (SOUZA, 1998; LANE, 2009). Após a desobstrução uretral, o material obstrutor é impelido ao interior da vesícula urinária, o que torna necessário realizar o processo de lavagem vesical com solução salina estéril ou de ringer com lactato, a fim de auxiliar na redução da hematúria e minimizar o risco de recorrência precoce de obstrução uretral (CORGOZINHO \& SOUZA, 2003; BARSANTI et al., 2004; RIESER, 2005). Após administrar cerca de $300 \mathrm{~mL}$ de soro pela sonda no processo de lavagem, verificamos se este volume de líquido foi o suficiente para amolecer os tampões uretrais ou remover os cristais, por meio de uma ligeira compressão manual da vesícula urinária criando uma pressão intra-uretral. A maioria dos tampões uretrais é expelida da uretra após está técnica, não havendo necessidade de cateterizar toda a uretra, pois o local mais comum de obstrução uretral é na uretra peniana que apresenta um diâmetro interno de $0,7 \mathrm{~mm}$ (SOUZA, 1998).

Após o restabelecimento do fluxo urinário, vários estudos demonstraram que alguns gatos obstruem novamente 24 a 48 horas após o alívio da obstrução primária, quando a sonda uretral não é fixada. Portanto, um cateter ou sonda flexível adequado para gatos deve ser introduzido cuidadosamente a fim de evitar trauma uretral e peniano, suturado ao prepúcio e conectado a um sistema coletor de urina 
fechado e estéril (RIESER, 2005; CORGOZINHO et al., 2007). O sistema de cateter fechado é caracterizado pela acoplagem da sonda urinária flexível ou cateter urinário conectada a um circuito fechado, que pode ser a um equipo com o frasco de soro vazio. Este sistema reduz a possibilidade de infecção bacteriana, e permite a aferição do débito urinário (MORAIS, 2004).

Recomenda-se a permanência da sonda urinária em sistema de cateter fechado por 24 a 48 horas em gatos que demonstraram elevado grau de dificuldade para desobstrução, ou quando em presença de intensa hematúria, ou ainda quando o calibre do fluxo urinário for fraco durante a micção. Após a retirada da sonda, recomenda-se que 0 animal fique hospitalizado por pelo menos 24 horas para avaliar a recorrência da obstrução, e verificar se o músculo detrusor da bexiga já recuperou a sua tonicidade (SOUZA, 1998; MORAIS, 2004; LANE, 2009).

2.4.3 Correção dos Desequilíbrios Hídrico, Eletrolítico e Ácido-básico.

A seguir são descritos alguns procedimentos a serem realizados visando reestabeler os desequilíbrios:

- Hipotermia: Gatos urêmicos são em geral hipotérmicos e devem ser aquecidos com colchão térmico, bolsas de água quente ou fluídos intravenosos mornos (SOUZA, 2003).

- Correção da Azotemia Pós-Renal: Felinos azotêmicos sem sinais clínicos podem ser tratados com fluidoterapia por via subcutânea na dosagem de 80 a $110 \mathrm{~mL} / \mathrm{kg} / \mathrm{dia}$. O volume inicial de fluido é calculado usando o peso do gato e o grau de desidratação, sendo administrado aproximadamente em 4 a 6 horas. Perdas hídricas como vômito ou diarréia devem ser corrigidos. O requerimento hídrico para a manutenção durante as primeiras 24 horas é calculado em $66 \mathrm{~mL} / \mathrm{kg}$. A fluidoterapia por via intravenosa tem também, como objetivo, compensar a diurese pós-obstrutiva que ocorre dentro de 12 a 24 horas após a desobstrução ( SOUZA, 2003)

- Hipercalemia: É um achado comum em animais obstruídos devido à incapacidade de eliminação dos íons potássio pela urina. O nível normal de 
potássio sérico é de 4,0 - 4,5 mEq/L, sendo que os efeitos cardíacos normalmente não ocorrem até a taxa de $7 \mathrm{mEq} / \mathrm{L}$ (OSBORNE et al., 2000). O eletrocardiograma poderá fornecer uma evidência presuntiva de hipercalemia, na impossibilidade de mensurar a concentração sérica de potássio nas primeiras duas horas de tratamento. O restabelecimento do fluxo urinário e a administração de fluídos por via intravenosa são os primeiros e mais importantes passos no tratamento da hipercalemia. A administração intravenosa de insulina regular $(0,5$ a $1 \mathrm{Ul} / \mathrm{kg})$ em conjunto com glicose (2 gramas/ UI de insulina) tem efeito direto sobre o potássio, pois transporta a glicose para o interior das células, carregando juntamente o potássio. Outra opção para a correção da hipercalemia é a adição de bicarbonato de sódio (\%déficit $\times 0,3 \times$ peso corporal $=$ quantidade total de bicarbonato $\mathrm{em} \mathrm{mEq}$ necessária para corrigir o pH para 7,4). É indicado aplicar de metade a um terço da dose em bolus intravenoso lento (10-15minutos). O bicarbonato de sódio também trata a acidose metabólica, porém pode diminuir ainda mais 0 cálcio ionizado (RIESER, 2005). A solução de gluconato de cálcio a 10\% antagoniza os efeitos cardiotóxicos do potássio, sendo usado como parte do tratamento da hiperpotassemia e pode ser injetado pela via intravenosa lentamente, não excedendo a dosagem de $1 \mathrm{~mL} / \mathrm{kg}$ (SCHAER, 1977). Segundo Soares et al. (2005), a terapia com bicarbonato de sódio só deve ser feita se houver acompanhamento por hemogasometria, e o antagonismo dos efeitos do potássio pela administração de gluconato de cálcio dura de 20 a 30 minutos.

- Acidose Metabólica: É causada pela retenção de ácidos, pelo consumo de bicarbonato para estabilizar o pH do plasma, pela produção de lactato, associada à hipovolemia e hipoxia e pela mínima conservação de bicarbonato no período obstrutivo e pós-obstrutivo. $\mathrm{O}$ pH do sangue, o dióxido de carbono e os níveis de bicarbonato são avaliados para realizar a terapia alcalinizante. A terapia é indicada quando o pH sangüíneo está abaixo de 7,2 utilizando a seguinte fórmula: $\mathrm{mEq}$ bicarbonato de sódio necessária $=\mathrm{kg} \times 0,3 \times$ déficit de bicarbonato ( $\mathrm{mEq} / \mathrm{L})$, sendo $50 \%$ administrado durante as primeiras 12 horas por via intravenosa e $25 \%$ nas próximas 12 horas. Caso não haja 
disponibilidade de dados laboratoriais, cerca de 1,5 a $2 \mathrm{mEq} / \mathrm{kg}$ de bicarbonato podem ser restituídos (SOUZA, 2003).

- Catabolismo: O gato obstruído encontra-se em estado catabólico, o que predispõe à lipidose hepática principalmente nos animais obesos. Uma dieta altamente palatável e calórica deve ser oferecida após o término dos episódios de vômito. Mudanças para rações terapêuticas só devem ser efetuadas após o retorno da apetência e estabilidade metabólica e hidroeletrolítica (SOUZA, 2003).

\subsubsection{Correções e Cuidados Após a Desobstrução}

- Hipocalemia: Gatos inicialmente hipercalêmicos pela obstrução podem se tornar hipocalêmicos durante a fluidoterapia. Além do mais, um período de intensa diurese ocorre após a desobstrução uretral, podendo levar a perda excessiva de potássio (CARTER et al., 1993). No felino hipocalêmico observa-se fraqueza muscular, caracterizada principalmente por ventroflexão do pescoço e letargia. A terapia é indicada quando o potássio sérico está abaixo de 3,5 a 3,8mEq/L, embora os sinais clínicos sejam visíveis quando esse se encontra abaixo de $2,5 \mathrm{mEq} / \mathrm{L}$. A hipocalemia pode ser corrigida acrescentando cloreto de potássio nos fluidos intravenosos (SCHAER, 1998). A quantidade depende da gravidade da hipocalemia, não podendo ultrapassar $0,5 \mathrm{mEq} / \mathrm{kg} / \mathrm{hora}$. O potássio pode ser empregado por via oral na ausência de vômitos, na dosagem de 1 a $2 \mathrm{mEq} / \mathrm{kg}$ dividido em três administrações ao dia (SOUZA, 2003).

- Cateter de espera: Facilita a monitorização do fluxo urinário, previne uma nova obstrução uretral imediata, mas pode induzir à infecção bacteriana no trato urinário e à irritação da uretra e vesícula urinária (SOUZA, 2003). O uso profilático de antibióticos não impede a infecção e parece selecionar bactérias mais resistentes. Portanto, os antibióticos não devem ser usados até que o cateter seja removido (ROSS, 1990).

É indicado em casos graves de hematúria, uremia, na presença de fluxo urinário curto e fino, presença de grandes quantidades de debris após 
várias irrigações vesicais e na deficiência do músculo detrusor (CARTER et al., 1993). Os felinos pós-obstrução podem apresentar atonia do músculo detrusor da bexiga devido à hiperdistensão grave ou prolongada da bexiga repleta de urina, e ocorre devido ao estiramento das fibras musculares e ruptura de porções especializadas das células musculares da bexiga denominadas junções íntimas, que transmitem os impulsos neurogênicos (CORGOZINHO \& SOUZA, 2003). Para o tratamento, esvazia-se a bexiga três a quatro vezes por dia ou permite-se que ela descanse por meio da cateterização e drenagem contínua. Há casos em que o tônus da bexiga é adequado, mas devido ao trauma da uretra há edema, o que dificulta a passagem de urina. Nesses casos, a prednisona é efetiva (KOLATA, 1984).

A estenose uretral pode ocorrer em decorrência de uretrite crônica ou repetidos traumas referentes à cateterizações, que pode levar à ruptura uretral. As lesões provocadas por cateterização inadequada, principalmente traumas penianos, estreitamento e inflamação da uretra, são as maiores complicações e tem indicação para uretrostomia (CORGOZINHO et al., 2007).

- 3) Lesão de reperfusão: Se a causa da isquemia for corrigida antes da ocorrência de alterações irreversíveis, o reestabelecimento circulatório que caracteriza a reperfusão proporciona as condições normais de metabolismo celular e da fisiologia do tecido. No entanto, o reestabelecimento circulatório pode não interromper o agravamento das alterações devido à isquemia, mas sim, intensificar esse processo com o retorno da circulação, o que denominase lesão de reperfusão, que é causada pela produção acentuada de radicais livres de oxigênio no tecido pós-isquêmico. Até o momento, já foi demonstrado que a lesão de reperfusão é importante na fisiopatologia do intestino, coração, musculatura esquelética, rins e pele (MATOS, 1999).

\subsubsection{Antibioticoterapia}

A antibioticoterapia tem sido utilizada não somente para as cistites bacterianas (ITU), mas também como profilaxia nos casos em que se utilizam cateteres urinários por 48 a 72 horas, após desobstrução uretral (GERBER et al., 2008). Porém, na ausência de bacteriúria em urinálise, a antibioticoterapia é 
relativamente contra-indicada enquanto o cateter urinário estiver em vigor, sendo indicada apenas após a sua retirada (RIESER, 2005).

Nas cistites bacterianas, a escolha do antibiótico deve ser baseada em resultados de cultura e teste de sensibilidade aos antimicrobianos selecionados. Porém, a maioria dos microorganismos isolados apresenta sensibilidade às fluorquinolonas como enrofloxacina, marbofloxacina e ciprofloxacina (LITSTER et al., 2007).

Reche Jr. (2005) verificou a eficácia de $100 \%$ da orbifloxacina no tratamento de cistites bacterianas, na dosagem de 2,5 mg/kg a cada 24 horas, durante 10 dias, sem sinais de nefrotoxicidade ou hepatotoxicidade, mesmo em gatos com Insuficiência renal crônica (IRC) compensada e azotemia. Nos animais que se mostraram resistentes à orbifloxacina, havia o histórico de complicações anteriores como recidivas de ITU secundária a IRC, diabete mellitus com controle glicêmico inadequado, e estenoses decorrentes de uretrostomia perineal, ou seja, eram animais portadores de infecção urinária crônica e o antibiograma demonstrou resistência não só à orbifloxacina como a todos os antibióticos testados. Tal fato pode ter ocorrido devido ao aumento da resistência bacteriana às quinolonas, por uso indiscriminado desses antibióticos em doses e períodos insuficientes.

\subsubsection{Agentes Antiinflamatórios e Analgésicos}

Estes agentes podem ser úteis no manejo de pacientes com desconforto decorrente de episódios agudos de $\mathrm{Cl}$, e na tentativa de reduzir a gravidade dos sinais clínicos, mas raramente são suficientes. Substância que vêm sendo usadas incluem o butorfanol $(0,2$ a 0,4 mg/kg, por via oral, ou subcutânea, a cada 8 a 12 horas), fentanil (1,0 a 5,0 $\mathrm{gg} / \mathrm{kg}$, IV), meloxicam $(0,1 \mathrm{mg} / \mathrm{kg}$, VO, a cada 24 horas, durante 3 a 4 dias) e o cetoprofeno (1 mg/kg / VO/ 24horas/3 a 4 dias) (SOUZA, 2003). Corticosteróides não parecem ser benéficos na redução de sinais clínicos de animais com Cl (GUNN-MOORE, 2003; FORRESTER, 2007b) e podem ocasionar efeitos gastrointestinais indesejáveis e toxicidade renal (GUNN-MOORE, 2003).

Steagall et al. (2006) verificaram em seu trabalho que morfina por via subcutânea, na dose de $0,02 \mathrm{mg} / \mathrm{kg}$ é o opióide mais efetivo no aumento do limiar a estímulos térmico e compressivo quando comparado a buprenorfina na dose de 0,02 $\mathrm{mg} / \mathrm{kg}$ e metadona na dose de $0,2 \mathrm{mg} / \mathrm{kg}$, sugerindo que, apesar de não possuir 
poder analgésico tão bom quanto a morfina, a metadona pode se mostrar uma boa opção alternativa na ultilização de opióides mu-agonistas (morfina, oximorfona, fentanil). Quando comparado pela via oral ou endovenosa, a buprenorfina se mostrou mais eficaz que os outros opióides testados, e o de melhor escolha para gatos.

\subsubsection{Amitriptilina}

A amitriptilina é um antidepressivo tricíclico, com propriedades anticolinérgicas, simpaticolíticas, analgésicas, que diminui a liberação de neurotransmissores no SNC, além de seu efeito anti-histamínico e anti-inflamatório vesical por diminuir a degranulação de mastócitos e conseqüentemente inibir a liberação de substâncias vasoativas (GUNN-MOORE, 2003; RECHE Jr., 2003). A amitriptilina induz potente relaxamento da musculatura lisa do trato urinário, que parece ser mediado pela abertura dos canais de potássio voltagem-dependente, através de um mecanismo bastante específico de ação (ACHAR et al., 2003).

A amitriptilina é uma substância com grande potencial para ser utilizada no tratamento de crises de dor induzidas por urolitíase (ACHAR et al., 2003). O uso de antidepressivos tricíclicos nos gatos deve ser cauteloso e reservado àqueles animais com doença grave ou crônica, que não responde a outras formas de terapia farmacológica, dietética e manejo ambiental. A dosagem da amitriptilina varia de 2,5 a 10 mg/gato, VO a cada 24 horas, administrados à noite (GUNN-MOORE, 2003).

Se não houver melhora dos sinais clínicos entre 2 a 4 meses de tratamento, a dosagem deve ser diminuída gradualmente por algumas semanas e então interrompida (GUNN-MOORE, 2003; KRUGER \& OSBORNE, 2009). Na dosagem de $2 \mathrm{mg} / \mathrm{kg}$, o fármaco parece controlar os principais sinais da CIF e os principais efeitos colaterais observados com seu uso crônico são sedação e o ganho de peso O uso da amitriptilina tem sido relacionado com mudança geral de atitude e diminuição do nível de atividade (RECHE Jr., 2003).

Efeitos colaterais leves com o uso em curto prazo incluem ataxia de membros pélvicos, e mudanças desejáveis no comportamento como se tornar menos agressivo (KRAIJER et al., 2003). Demais efeitos colaterais incluem a retenção urinária, infecção do trato urinário, sonolência, hiperbilirrubinemia, aumento da concentração plasmática de alanino aminotransferase (ALT), neutropenia, 
trombocitopenia, midríase e embora seja rara, a hiperexcitabilidade tem sido relatada em poucos cães tratados com amitriptilina. A função hepática deve ser avaliada antes de iniciar a terapia, após um mês e posteriormente a cada 6 a 12 meses enquanto o animal estiver em tratamento (GUNN-MOORE, 2003; KRUGER \& OSBORNE, 2009).

A amitriptilina na dose de $10 \mathrm{mg}$ uma vez ao dia não é benéfica para terapia de curto prazo (sete dias) na DTUIF, enquanto o tratamento prolongado, por várias semanas a meses, pode ser útil (GUNN-MOORE, 2003). Kruger et al. (2003) não observaram diferença na taxa de recuperação de polaquiúria e hematúria entre o grupo de gatos com DTUIF não obstrutiva tratados por um curto prazo com amitriptilina e o grupo controle. Os sinais clínicos recidivaram significativamente mais rápido e mais freqüentemente no grupo tratado com amitriptilina do que no grupo controle.

Portanto, os resultados sugerem que o tratamento em curto prazo com mitriptilina não tem benefício em termos de resolução de polaquiúria e hematúria na DTUIF e pode ser associado com aumento do risco de recidivas (KRUGER et al., 2003).

\subsubsection{Antiespasmódicos}

O tratamento do espasmo uretral pode reduzir a gravidade dos sinais clínicos em alguns gatos, e pode reduzir o risco de recorrência de bloqueio uretral. Fibras musculares lisas e esqueléticas são responsáveis por gerar tônus uretral. Medicamentos injetáveis podem ser administrados para alívio momentâneo da obstrução como a acepromazina (0,05 - 0,2 mg/kg, IV/ IM/ SC). Após a abordagem inicial, pode-se prescrever fármacos antiespasmódicos de uso oral por um período de 7 a 14 dias, devendo fazer diminuição progressiva da dose e aumento do intervalo de administração ao longo de alguns dias e então, interromper o tratamento. Estas substâncias incluem os antagonistas dos alfa adrenorreceptores não seletivos como a fenoxibenzamina $(0,5$ a $1,0 \mathrm{mg} / \mathrm{kg}$, VO, a cada 12 horas) e outro mais seletivo, a prazosina (0,25 a 1,0 mg/gato, VO, a cada 8 a 12 horas), com efeito colateral sedativo. Outra opção é o dantrolene $(0,5$ a 2,0 mg/kg, VO, a cada 12 horas). Este último atua sobre a musculatura esquelética, e os demais sobre a 
musculatura lisa. Os efeitos colaterais incluem hipotensão e hepatotoxicidade (GUNN-MOORE, 2003; WESTROPP, 2007).

Devido ao potencial para efeitos adversos e a falta de ensaios clínicos para estabelecer as doses e a eficácia, os agentes dessa categoria não são atualmente recomendados para a terapêutica de rotina de gatos com CIF (NORWORTHY, 2009).

\subsubsection{Glicosaminoglicanos}

O tratamento com glicosaminoglicanos (GAGs) tem sido sugerido em felinos com CIF, pois defeitos na camada de GAGs que recobrem o epitélio vesical podem desempenhar papel na patogênese da doença. Estes agentes têm sido mencionados como úteis em humanos e gatos com CIF, por atuar como protetores do urotélio e reduzir a permeabilidade da parede vesical, além de efeitos analgésicos e antiinflamatórios. O polissulfato de pentosano sódico (8 A 10mg/kg, VO, a cada 12 horas), ou a combinação de hidrocloreto de glucosamina com sulfato de condroitina (90mg, VO, a cada 24 horas) demonstraram eficácia nos gatos (NORSWORTHY, 2009). Alguns efeitos colaterais podem incluir prolongamento do tempo de sangramento, inapetência, e possivelmente, resistência à insulina (GUNNMOORE, 2003; FORRESTER, 2007b). O tratamento deve ser de no mínimo de 30 dias para fazer efeito (NORSWORTHY, 2009).

\subsubsection{Tratamento Dietético}

Uma vez que os constituintes dos alimentos influenciam o volume, $\mathrm{pH}$ e concentração dos solutos na urina, a dieta pode contribuir para a etiologia, tratamento e prevenção de recorrências de algumas causas da DTUIF (MARKWELL et al., 1998).

Para a redução de recidivas de formação de cálculos são utilizadas dietas calculolíticas comerciais que são restritas em magnésio, suplementadas com sal para estimular o consumo hídrico, tendo como objetivos alcançar um pH urinário inferior a 6,3 e uma densidade urinária inferior a 1.030 .

Atualmente há disponível no mercado brasileiro três marcas com rações destinadas ao tratamento e prevenção de cálculos sendo elas: Royal Canin, Purina e 
Hill's. Segue abaixo (Quadro 1) as indicações de cada ração para dissolução ou prevenção de cálculos.

Quadro 1 - Relação das rações disponíveis no mercado brasileiro para tratamento de DTUIF. (Adaptado de Bowles, 2008).

\begin{tabular}{|c|c|c|c|c|c|c|c|c|c|c|c|c|}
\hline \multirow{2}{*}{\begin{tabular}{|l} 
Urólito \\
Dieta \\
\end{tabular}} & \multicolumn{2}{|c|}{ Estruvita } & \multicolumn{2}{|c|}{ Oxalato de Cálcio } & \multicolumn{2}{|c|}{ Urato } & \multicolumn{2}{|c|}{ Xantina } & \multicolumn{2}{|c|}{ Cistina } & \multicolumn{2}{|c|}{ Silica } \\
\hline & $\mathrm{D}^{*}$ & $\mathrm{P}^{*}$ & $\mathrm{D}$ & $\mathrm{P}$ & $\mathrm{D}$ & $\mathrm{P}$ & $\mathrm{D}$ & $\mathrm{P}$ & $\mathrm{D}$ & $\mathrm{P}$ & $\mathrm{D}$ & $\mathrm{P}$ \\
\hline Hill's Prescription Diet c/d Multicare & & 0 & & $\mathrm{O}$ & & & & 0 & & & & \\
\hline Hill's Prescription Diet k/d & & & & & 0 & 0 & & & & 0 & & \\
\hline Hill's Prescription Diet s/d & 0 & & & & & & & & & & & \\
\hline Hill's Prescription Diet w/d & & 0 & & 0 & & & & & & & & \\
\hline Purina UR st/ox Formula & & 0 & & O & & & & & & & & \\
\hline Royal Canin Control Formula & & 0 & & & & & & & & & & \\
\hline Royal Canin Dissolution Formula & 0 & & & & & & & & & & & \\
\hline Royal Canin Urinary SO \& SO 33 & 0 & & & 0 & & & & & & & & \\
\hline
\end{tabular}

* $\mathrm{D}=$ dissolução, $\mathrm{P}=$ prevenção

\subsubsection{Intervenção Cirúrgica}

O procedimento cirúrgico deve ser considerado quando houver insucesso na tentativa de desobstrução uretral, ou quando a terapia medicamentosa e dietética em longo prazo, não atingir seu objetivo (WILLIAMS, 2009). Também é indicada nos casos de DTUIF obstrutiva recidivante (CORGOZINHO et al., 2007). A correção das alterações metabólicas e do desequilíbrio hidroeletrolítico é fundamental na preparação do felino para a intervenção cirúrgica (SOUZA, 2003). A escolha da técnica cirúrgica será determinada pela causa da obstrução e sua localização na uretra, incluindo a cistotomia, cistotomia combinada com uretrostomia, uretrostomia perineal, uretrostomia pré-púbica e uretrostomia transpélvica (WILLIAMS, 2009). A uretrostomia perineal é a técnica mais indicada para os casos de DTUIF (CORGOZINHO et al., 2007; WILLIAMS, 2009).

As complicações mais freqüentes inerentes às técnicas de uretrostomias são as estenoses uretrais e as infecções urinárias bacterianas recorrentes (HOSGOOD \& HEDLUND,1992). Esses animais toleram bem o pós operatório e tem boa qualidade de vida em longo prazo (CORGOZINHO et al., 2007). Gerber et al. (2008) afirmam que o prognóstico é reservado, pois os sinais clínicos e a obstrução uretral (independente da causa) podem recorrer, visto que a cirurgia apenas corrige a obstrução uretral, e não a doença subjacente, necessitando continuidade da terapia 
medicamentosa ou dietética instaurada (CORGOZINHO et al., 2007; GERBER et al., 2008; WILLIAMS, 2009).

\subsection{Prognóstico}

Muitos casos de DTUIF não obstrutiva são autolimitantes, e usualmente se resolvem entre 7 a 14 dias (NORSTWORTHY, 2009). No entanto, a maioria dos gatos afetados tem episódios recorrentes de sinais clínicos, com variável freqüência e gravidade, que diminuem ao longo do tempo. Portanto, para esses animais o prognóstico é bom a curto prazo e excelente em longo prazo (GUNN-MOORE, 2003). Para aqueles gatos com obstrução uretral, o prognóstico em longo prazo é reservado. Cinquenta e um por cento dos animais com obstrução uretral tem recorrência dos sinais clínicos de doença do trato urinário inferior, independente da causa de obstrução. Muitos gatos que foram submetidos à uretrostomia devido a complicações da DTUIF apresentam uma boa qualidade de vida após a cirurgia (CORGOZINHO et al., 2007).

Grande parte dos animais com recidiva é submetida à eutanásia por opção dos proprietários frente a insucessos na terapia. Assim, justifica-se a importância de fornecer informações realistas sobre o prognóstico desta doença dispendiosa para evitar decepções após tentativas de tratamento.

\subsection{Prevenção}

\subsubsection{Redução de Estresse}

Nos casos onde há piora dos sinais clínicos frente às situações estressantes, os proprietários não devem submeter seus gatos a condições adversas. Isso muitas vezes é difícil, visto que uma simples modificação na dieta ou no manejo higiênico pode ser estressante para alguns gatos (RECHER Jr., 2003; RECHE Jr. \& HAGIWARA, 2004). Os fatores estressantes incluem viver com outro gato o qual ele não gosta, mudanças bruscas na alimentação, alterações de ambiente ou tempo, superlotação, estresse com proprietário ou ainda adição de novas pessoas ou 
animais na casa. Medidas para redução do estresse devem ser abordadas com o proprietário. Aqui estão algumas delas:

1) Enriquecer o ambiente para gatos que permanecem no interior de casa com brinquedos e espaço, estimulando a realizarem atividade física.

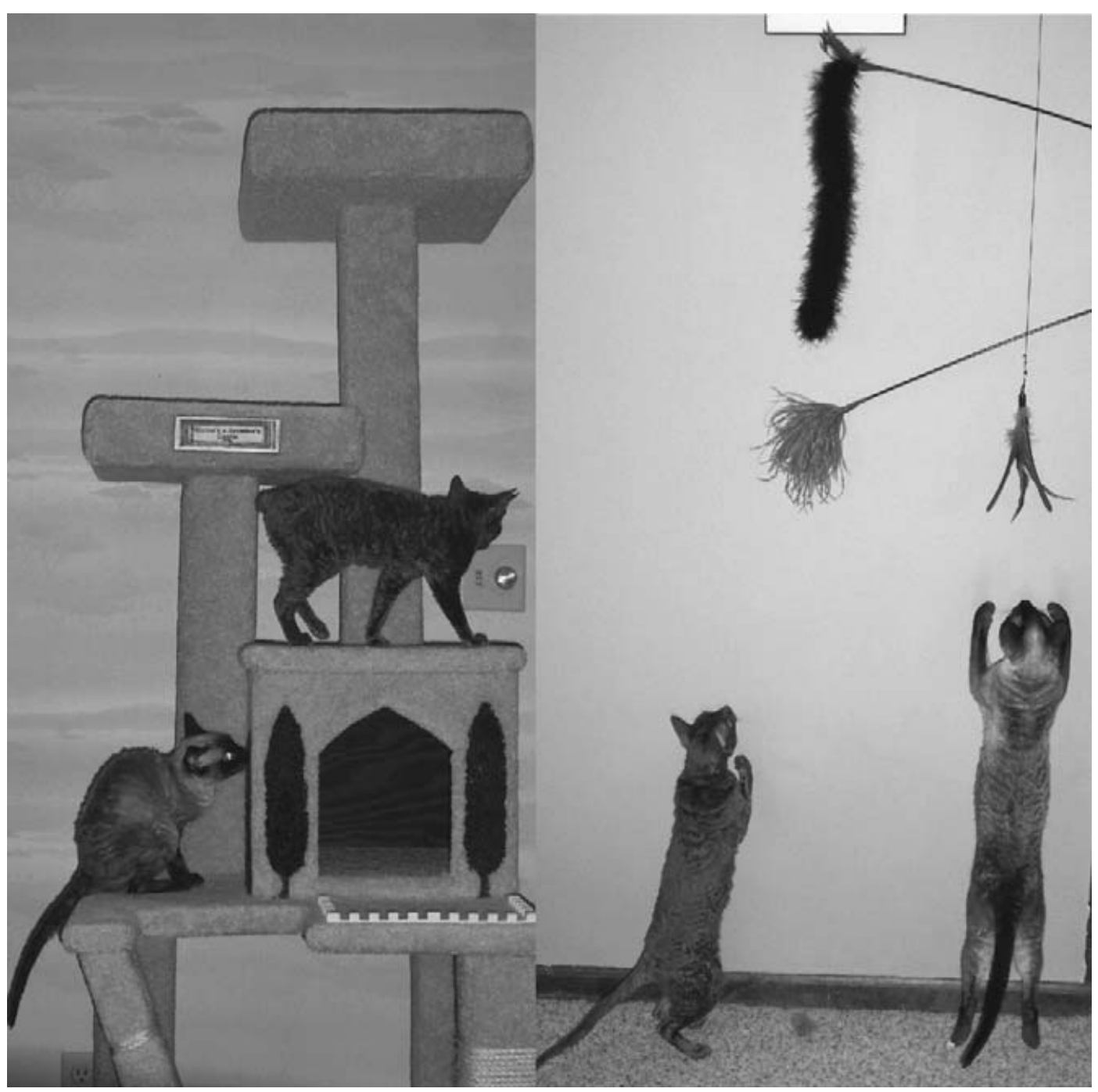

Figura 11 - Enriquecimento ambiental de brinquedos para redução do estresse em gatos com DTUIF. (Adaptado de Hostutler et al. 2005).

2) Fornecer número adequado de caixas com quantidade adequada de areia e limpá-las frequentemente. O número de caixas deve ser igual ao número de animais presentes na casa mais um, ou seja, o número de caixas é sempre maior do que número de animais. Providenciar local acessível e seguro para as caixas de 
areia do gato, não colocando-as perto do local onde se alimentam, pois eles não defecam ou urinam no mesmo local em que comem.

3) Reduzir a superlotação. O excesso de gatos em um mesmo ambiente leva a lutas territoriais, principalmente na presença de fêmeas em cio.

4) Fornecer locais seguros para o animal além de "esconderijos"; tranqüilizar o gato sempre que possível e aumentar a interação proprietário-gato;

5) Considerar o uso do Feliway® (ferormônio facial felino sintético) no ambiente para redução de ansiedade (GUNN-MOORE, 2003; KRUGER \& OSBORNE, 2009).

\subsubsection{Dieta e Consumo Hídrico}

1) Estimular a ingestão de água do felino através da limpeza freqüente dos potes e fornecimento de água sempre fresca (água mineral, se possível). Potes de barro/cerâmica auxiliam a manter a água em temperatura mais fresca. Os potes devem ficar em locais sombreados e espalhados pela casa, para que o animal não se prive de ingerir água devido à distância imposta (Westropp, 2007).

2) Fornecer alimentação de preferência de forma livre (à vontade) ao invés de estabelecer horários próprios. Os gatos possuem hábitos diferentes de alimentação quando comparados aos cães, e se alimentam em pequenas porções, várias vezes ao dia. Sabe-se que a alimentação ad libitum resulta em onda alcalina pós-prandial de menor magnitude quando comparada à alimentação sob a forma de refeições diárias menos freqüentes $(\mathrm{SKOCH}, 1991)$. A onda alcalina pós-prandial ocorre em conseqüência da secreção gástrica de ácido clorídrico quando da ingestão do alimenta. Quanto mais intensa for a secreção gástrica com perda de ácidos para a luz intestinal, maior será a compensação orgânica, com a eliminação de bicarbonato via rins, o que determina a formação de urina alcalina. Portanto, o confinamento a que estes animais ficam expostos, assim como o livre acesso ao alimento, pode contribuir para a ingestão mais freqüente de pequenas porções de ração, levando à produção de urina menos alcalina (FINKE \& LITZENBERGER, 1992).

3) Fornecer rações de boa qualidade e se possível, oferecer ração úmida (lata ou sache) de forma pura ou misturada à ração seca. 


\section{CONSIDERAÇÕES FINAIS}

Felinos com DTUIF são um grande desafio diagnóstico e terapêutico para o clínico veterinário. Os sinais clínicos hematúria, disúria, polaquiúria e periúria são comuns em várias doenças, dificultando a elaboração de um diagnóstico preciso e de um tratamento efetivo.

A etiologia pode ser multifatorial ou, em muitos dos casos ser idiopática. A Cistite Idiopática Felina juntamente com a urolitíase são as principais causas de DTUIF, se encontrando em primeira e segunda posição, respectivamente.

O diagnóstico é realizado através do histórico e da anamnese, concomitantemente à avaliação clínica e aos exames complementares. Deve-se também avaliar a influência de fatores predisponentes como idade, sexo, estado reprodutivo, manejo sanitários incorretos, fatores estressantes, sedentarismo, obesidade, dieta, freqüência de alimentação e consumo hídrico.

O tratamento é realizado de acordo com os sinais clínicos apresentado pelo felino, variando de antibioticoterapia, antiinflamatórios até antidepressivo. A DTUIF pode se apresentar com ou sem obstrução, sendo os casos obstrutivos considerados emergenciais, já que podem levar o animal a óbito em questão de poucas horas.

O prognóstico é positivo quando as alterações ocasionadas pela azotemia pós-renal são revertidas a tempo, porém as recidivas podem ocorrer, principalmente quando o tratamento preventivo não é seguido a risca pelos proprietários, podendo estes optarem pela eutanásia do felino devido ao insucesso frente à terapia.

A prevenção para evitar novas recidivas está praticamente no manejo dos felinos, evitando o estresse do animal, estimulando o consumo hídrico e uma dieta nutricional adequada. É necessária a instrução dos proprietários dos animais sobre os fatores de riscos e sobre as atitudes mais adequadas para diminuir o surgimento da doença. 


\section{REFERÊNCIAS BIBLIOGRÁFICAS}

ACHAR, E.; ACHAR, R.A.N.; PAIVA, T.B. et al. Amitriptyline eliminates calculi through urinary tract smooth muscle relaxation. Kidney International v.64, p.13561364, 2003.

ADAMAMA-MORAITOU, K.K.; PAITAKI, C.G.; RALLIS, T.S. et al. Aspergillus species cystitis in a cat. Journal of Feline Medicine and Surgery v.3, p.31-34, 2001.

ALBERTS, B.; BRAY, D.; LEWIS, J. et al. Relato de caso. Arquivo Brasileiro de Medicina Veterinária e Zootecnia v.59, n.4, p.943-947, 2007.

BALBINOT, P.Z.; VIANA, J.A.; BEVILAQUA, P.D. et al. Distúrbio Urinário do Trato Inferior de Felinos: Caracterização de Prevalência e Estudo de Casos-Controle em Felinos no Período de 1994-2004. Revista Ceres v.310, n.53, p. 549-558, 2006.

BARSANTI, J.A.; FINCO, D.R.; BROWN, S.A. Diseases of the lower urinary tract. In: Sherding, R.G. The Cat Diseases and Clinical Management. $2^{\text {nd }}$ Ed., Sydney: WB Saunders p.1769-1817, 2004.

BARTGES, J.W.; FINCO, D.R.; POLZIN, D.J. et al. Pathophysiology of urethral obstruction. Veterinary Clinics of North America: Small Animal Practice v. 26, n.2, p. 255-264, 1996.

BARTGES, J.W. Feline lower urinary tract cases. Proceedings American College of Veterinary Internal Medicine Forum v. 21, p. 167-170, 2003.

BOWLES, M. Stalking stones: An overwiew of canine and feline urolithiasis. Veterinary Medicine, 2008. Disponível em: <http://veterinarymedicine.dvm360.com. > Acesso em: 12 de agosto de 2010.

BUFFINGTON, C.A.T.; ROGERS, Q. R.; MORRIS, J. C. Effect of diet on struvit activity product in feline urinary. American of Journal Veterinary Research v. 151, p. 2025 - 2030, 1990.

BUFFINGTON, C.A.T.; BLAISDELL, J.L.; TOSHINORI, S. Effects of Tam-Horsfall glycoprotein and albumin on struvit crystal growth in urine of cats. American of Journal Veterinary Research v. 55, n. 7, p. 965 - 971, 1994.

BUFFINGTON, C.A.T.; CHEW D.J.; KENDALL M.S. et al. Clinical evaluation of cats with nonobstructive urinary tract diseases. Journal of American Veterinary Medicinal Association v.210, p. 46-50, 1997.

BUFFINGTON, C. A.T.; CHEW, D. J. Calcium oxalate urolithiasis in cats. Journal of Endourology v.13, n.9, p.659-663, 1999.

BUFFINGTON, .C.A.T.; Feline lower urinary uroliths (flutd). Urology Nutrition v.21, p.401-450, 2001. 
BURGER, I.; ANDERSON, R.S.; HOLME, D.W. Nutritional factors affecting water balance in dog and cat. In: Anderson, R.S. (ed). Nutrition of the Cat and Dog Pergamon Press, Oxford, p.145-156, 1980.

CARMONA, M.J.C.; MENDONÇA, M.R.F. Distúrbios hidroeletrolíticos e anestesia. In: Fantoni, D.T.; Cortopassi, S.R.G. Anestesia em cães e gatos. $1^{\text {a }}$ Ed., São Paulo: Roca, p. 130-139, 2002.

CARTER, W.O.; HAWKINS, E.C.; MORRISON, W.B. Feline Nephrolithiasis: Eight Cases (1984 Through 1989). Journal of the American Animal Hospital Association v.29, p.247-255, 1993.

CAVANA, P.; ZANATTA, R.; NEBBIA, P. et al. Corynebacterium urealyticum urinary tract infection in a cat with urethral obstruction. Journal of Feline Medicine and Surgery v.10, p.269-273, 2008.

CORGOZINHO, K.B.; SOUZA, H.J.M. Condutas na Desobstrução Uretral. In: Souza, H.J.M. Coletâneas em Medicina e Cirurgia Felina. Rio de Janeiro: LF livros, c.6, p.67-88, 2003.

CORGOZINHO, K.B.; SOUZA, H.J.M.; PEREIRA, A.M. et al. Catheter-induced urethral trauma in cats with urethral obstruction. Journal of Feline Medicine and Surgery v.9, p.481-486, 2007.

COWAN, L.A. Uretropatias. In: Sherding, B. Manual Saunders: Clínica de Pequenos Animais 1를. Eão Paulo: Roca, c.5, p.949-955, 1998.

COWGILL, L. D. Acute renal failure: causes and outcomes. Proceedings International Veterinary Emergency and Critical Care Symposium v.9, p.383387, 2003.

EGGERTSDÓTTIR, A.V.; LUND, H.S.; KRONTVEIT.R. et al. Bacteriuria in cats with feline lower urinary tract disease: a clinical study of 134 cases in Norway. Journal of Feline Medicine and Surgery v.9, p.458-465, 2007.

ELAM, M.; THORÉN, P.; STEVENSSON, T.H. Locus coeruleus neurons and sympathetic nerves: activation by visceral afferents. Brain Research v.375, n.1, p.117-125, 1986.

FELÍCIO, A.C. Doença idiopática do trato urinário inferior dos felinos (DITUIF). 2009. 80 p. Relatório de estágio supervisionado e relato de caso (Clínica Médica e Cirúrgica de Pequenos Animais) - Universidade Estadual do Norte do Paraná, Bandeirantes, 10 jun 2009.

FINCO, D.R.; CORNELIUS, L.M. Characterization and Treatment of Water, electrolyte, and Acid-Base Imbalances of Induced Urethral Obstruction in the Cat. American Journal Veterinary Research v.38, n.6, p.823-830, 1977.

FINKE, M.D.; LITZENBERGER, B.A. Effect of food intake on urine $\mathrm{pH}$ in cats. Journal of Small Animal Practice v.33, n.6, p.261-5, 1992. 
FISCHER, J.R.L. Functional Urinary Obstruction. Philadelphia: Hanley \& Belfus, p.232-235, 2001.

FORRESTER, S.D. Approach diagnosis for hematuria in dogs and cats. The Veterinary Clinics of North America: Small Animal Practice v.34, n.4, p. 849-66, 2004.

FORRESTER, S.D. FLUTD: How important is it? Proceedings of the 2007 Hill's FLUTD Symposium p.5-11, 2007a.

FORRESTER, S.D. FLUTD: Are you choosen the right therapy? Part 2. Feline Idiopathic Cystitis. Proceedings of the 2007 Hill's FLUTD Symposium p.37-43, 2007b.

FUNABA, M.; HASHIMOTO, M.; YAMANAKA, C. et al. Effects of a high - protein diet on mineral metabolism and struvit activity product in clinically normal cats. American of Journal Veterinary Research v. 57, n. 12, p. 1726 - 1732, 1996.

GAO, X.; BUFFINGTON, C.A.; AU, J.L.S. Effect of interstitial cystitis on drug absorption from urinary bladder. Journal of Pharmacology \& Experimental Therapeutics v.271, n.2, p.818-23, 1994.

GERBER, B.; BORETTI, F.S.; KLEY, S. et al. Evaluation of clinical and signs causes of lower urinary tract disease in European cats. Journal of Small Animal Practice v.46, p. 571-577, 2005.

GERBER, B.; EICHENBERGER, S.; REUSCH, C.E. Guarded long-term prognosis in male cats with urethral obstruction. Journal of Feline Medicine and Surgery v.10, p.16-23, 2008.

GLOWASKI, M.M.; WETMORE, L.A. Propofol: Application in Veterinary Sedation and anesthesia. Clinical Techinques in Small Animal Practice v.14, n.1, p.1-9, 1999.

GRAUER, G.F. Distúrbios urinários. In: Nelson, R.W.; Couto, C.G. (eds.) Fundamentos de Medicina Interna de Pequenos Animais. São Paulo: Guanabara Koogan, p.329-343, 1994.

GRAUER, G.F. Urinary Tract Disorders. In: Nelson, R.W. and Couto, G. (eds.) Small Animal Internal Medicine. St. Louis: USA, Mosby p.816-827, 2003.

GREEN, S.A.; GRAUER, G.F. Renal disease. In: Tranquilli, W.J.; Thurmon, J.C.; Grimm, K.A. (eds.) Lumb \& Jones Veterinary Anesthesia and Analgesia, $4^{\text {th }} \mathrm{Ed}$., Lowa: Blackwell p.915-919, 2007.

GUNN-MOORE, D.A. Feline lower urinary tract disease. Journal of Feline Medicine and Surgery v.5, p.133-138, 2003.

GUNN-MOORE, D.A.; SHENOY, C.M. Oral glucosamine and the management of feline idiopathic cystitis. Journal of Feline Medicine and Surgery v.6, p.219-225, 2004. 
HOLT, P.E. Enfermidades del tracto urinario inferior en gatos; tratamiento quirúrgico. Ediction Especial: Estúdio Del Tracto Urinário. Walthan Focus p. 42 - 47, 1998.

HOSGOOD, G.; HEDLUND, C.S. Perineal Urethrostomy in Cats. The Compendium on Continuing Education for the Practicing Veterinarian v.14, n.9, p. $323-331$, 1992.

HOSTUTLER, R.A.; CHEW, D.J.; DIBARTOLA, S.P. Recent concepts in feline lower urinary tract disease. The Veterinary Clinics of North America: Small Animal Practice v.35, p.147-170, 2005.

HOTEL, L. M. Preapuberal gonadectomy - early - age neutering of dogs and cats. IVIS International Veterinary Information Service, 2000. Disponível em: $<$ http://www.ivis.org/home.asp>. Acesso em 15 de agosto de 2010.

HOUSTON, D.M.; MOORE, A.E.; FAVRIN, G., et al. Feline urethral plugs and bladder uroliths: a review of 5484 submissions 1998-2003. Canadian Veterinary Journal p. 974-777, 2006.

HOUWERS, D.J.; VAN DONGEN, A.M. PCR-based detection reveals no causative role for Mycoplasma and Ureaplasma in feline lower urinary tract disease. Veterinary Microbiology v.116, p.246-247, 2006.

HUEB, A. C.; KALAÁS, E. Alterações ácido-básicas na insuficiência renal. In: Gomes, O. M. Interpretação clínica das alterações ácido-básicas e distúrbios da oxigenação. 1ํㅡㄹ. Ed., Belo Horizonte: Editora Coração Ltda, p. 256, 1997.

HURLEY, K.J. Tratamiento da emergencia de la obstrucción uretral felina. Ediction Especial: Estúdio del Tracto Urinário. Walthan Focus p.33 - 37, 1998.

HURST, R. E.; ROY, J.B.; MIN, K. W. A deficit of chondroitin sulfate proteoglycans on the bladder uroepithelium in interstitial cystitis. Urology v. 48, n. 5, p. 817-821, 1996.

KRAIJER, M.; FINK-GREMMELS, J.; NICKEL, R.F. The short-term clinical efficacy of amitriptyline in the management of idiopathic feline lower urinary tract disease: a controlled clinical study. Journal of Feline Medicine and Surgery v.5, p.191-196, 2003.

KRUGER, J.M.; OSBORNE, C.A.; GOYAL S.M. et al. Clinical Evaluation of Cats with Lower Urinary Tract Disease. Journal of the American Veterinary Medical Association v.199, n.2, p.211-215, 1991.

KRUGER, J.M.; CONWAY, T.S.; KANEENE, J.B., et al. Randomized controlled trial of the efficacy of short-term amitriptyline administration for treatment of acute, nonobstructive, idiopathic lower urinary tract disease in cats. Journal of the American Veterinary Medical Association v.222, n.6, p.749-758, 2003. 
KRUGER, J.M.; OSBORNE, C.A.; LULICH, J.P. Changing paradigms of feline idiopathic cystitis. The Veterinary Clinics of North America: Small Animal Practice v.39, p.15-40, 2008.

KRUGER, J.M.; OSBORNE, C.A. Manegement of feline nonobstrutive idiopathic cystitis. In: Bonagura, J.D. e Twedt, D.C. Kirk's Current veterinary therapy $14^{\text {th }}$ Ed., Missouri: Saunders Elsevier p.944-950, 2009.

LANE, I. Urethral obstruction in cats: Catheters and complications (Proceedings): CVC, 2009. Disponível em: $<$ http://veterinarycalendar.dvm360.com/avhc/Feline+medicine/Urethral-obstruction-incats-Catheters-and-complic/ArticleStandard/Article/detail/608438>. Acesso em: 11 de agosto de 2010.

LEKCHAROENSUK, C.; OSBORNE, C.A.; LULICH, J.P. Epidemiologic study of risk factores for lower urinary tract diseases in cats. Journal of the American Veterinary Medical Association v.218, n.9, p.1429-1435, 2001.

LEWIS, L.D.; MORRIS, M.L.; HAND ,M.S. Feline urologie syndrome (FUS). In: Small Animal Clinical Nutrition III, Mark Morris Associates, Topeka, KS p.93, 1987.

LIMA, E.R.; REIS, J.C.; ALMEIDA, E.L. et al. Influência do tipo de dieta e tempo de consumo sobre os parâmetros eletrolíticos em gatos domésticos (Felis domesticus, Linnaeus, 1758). Acta Scientiae Veterinariae v.35, n.2, p.500-502, 2007.

LITSTER, A.; MOSS, S.M.; HONNERY, M. et al. Prevalence of bacterial species in cats with clinical signs of lower urinary tract disease: Recognition of Staphylococcus felis as a possible feline urinary tract pathogen. Veterinary Microbiology v.121, p.182-188, 2007.

LITSTER, A.; MOSS, S.M.; PLATELL, J. et al. Occult bacterial lower urinary tract infections in cats: Urinalysis and culture findings. Veterinary Microbiology v.136, p.130-134, 2008.

LULICH, J.P.; OSBORNE, C.A. Catheter assisted retrieval of urocystoliths from dogs and cats. Journal of the American Veterinary Medical Association v.201, p.111 113, 1992.

LULICH, J.P.; OSBORNE, C.A.; CARLSON, M., et al. Nonsurgical removal of urocystoliths in dogs and cats by voiding urohydropropulsion. Journal of the American Veterinary Medical Association v. 203, p.660-638, 1993.

LUNA, S.P.L. Equilíbrio ácido-básico. In: Fantoni, D.T.; Cortopassi, S.R.G. (eds.) Anestesia em cães e gatos. $1^{\text {a }}$ Ed., São Paulo: Roca c.10, p. 120-129, 2002. 
MARKWELL, P.J.; BUFFINGTON, C.A. Feline lower urinary tract disease. In: Wills, J. M.; Simpson, K.W. (eds.). The Waltham Book of clinical nutrition of the dog and the cat. Oxford: Pergamon Press p. 293-312, 1994.

MARKWELL, P.J.; BUFFINGTON, C.A., SMITH, B.H. The effect of diet on lower urinary tract diseases in cats. The Journal of Nutrition v.12, n.128, p.2753-2757, 1998.

MATOS, J.J.R.T. Lesões de isquemia e reperfusão experimentais no jejuno de equinos: tratamento com succinato sódico de hidrocortisona, 1999, 97p. Tese de Mestrado (Medicina Veterinária). Faculdade de Medicina Veterinária, Universidade Federal de Minas Gerais, Belo Horizonte.

MATSUMOTO, K.; FUNABA, M. Factors affecting struvite $\left(\mathrm{MgNH}_{4} \mathrm{PO}_{4} \cdot 6 \mathrm{H}_{2} \mathrm{O}\right)$ crystallization in feline urine. Biochimica et Biophysica Acta v.1780, p. 233-239. 2008.

MELER, E.; PRESSLER, B. Research Updates. How often do uroliths really recur in cats? Veterinary Medicine, 2010. Disponível em: <http://www.dvm360.com/> Acesso em: 20 de outubro de 2010.

MOORE, A. Quantitative analysis of urinary calculi in dogs and cats. Veterinary Focus v.17, n.1, p.22-27, 2007.

MORAIS, H.A. Manejo Emergencial do Gato Obstruído. In: IV CONFERÊNCIA SULAMERICANA DE MEDICINA VETERINÁRIA, 2004, Rio de Janeiro. Anais... Rio de Janeiro, CD-ROM.

NORSWORTHY, G.D. Cistite idiopática felina. In: Norsworthy, G.D.; Crystal, M.A.; Grace, S.F; Tilley, L.P. (eds.) O Paciente Felino. 3ª Ed., São Paulo: Roca p. 95-98, 2009.

OSBORNE, C.A.; JOHNSTON, G.R.; KRUGER, J.M. et al. Etiopathogenesis and biological behavior of feline vesicourachal diverticula: don't just do something stand there. Veterinary Clinics of North America: Small Animal Practice v.17, n.3, p.697-773, 1987.

OSBORNE, C.A.; POLZIN, D.; KRUGER, J.M. et al. Relationship of nutritional factors to the cause, dissolution and prevention of feline uroliths and urethral plugs. Veterinary Clinics of North America: Small Animal Practice v. 19, n.3, p. 561$581,1989$.

OSBORNE, C.A.; KRUGER, J.P.; LULICH, L.P. et al. Feline matrixcrystalline urethral plugs: a unifying hypothesis of causes. Journal of Small Animal Practice v.33, n.4, p.172-7, 1992.

OSBORNE, C.A.; KRUGER, J.M.; LULICH, J.P. et al. Feline lower urinary tract diseases. In: Ettinger, S. J. and Feldman, E.C. (eds.) Textbook of veterinary Internal Medicine. Philadelphia: Saunders Company v. 2, p. 1805 - 1832, 1995. 
OSBORNE, C.A.; LULICH, J.P.; POLZIN, D.G. et al. Analysis of 77,000 canine uroliths: Perspectives from the Minnesota Urolith Center. In: Osborne, C.A.; Lulich, J.P.; Bartges, J.W. (eds.) Veterinary Clinical of North America: Small Animal Practice v.29, p.17-38, 1999.

OSBORNE, C.A.; KRUGER J.M.; LULICH, J.P. et al. Doenças do trato urinário inferior dos felinos. In: Ettinger, S.J.; Feldman, E.C. (eds.) Tratado de Medicina Interna Veterinária: Doenças do cão e do gato. 5aㅡ. Ed., Rio de Janeiro: Guanabara Koogan v.2 p.1802-1841, 2004.

OSBORNE, C.A. Is your crystalluria interpretation crystal clear? DVM Newsmagazine, mai 2010a. Disponível em: <http://www.dvm360.com/> Acesso em: 20 de outubro de 2010.

OSBORNE, C.A. Epidemiology of feline uroliths and urethral plugs: Update 1981 to 2009. Changes in feline diets may relate to changes in urolith composition. DVM Newsmagazine, jun 2010 b. Disponível em: <http://www.dvm360.com/> Acesso em: 21 de outubro de 2010.

PARSONS, C.L.; BOYCHUK, D.; JONES, S. et al. Bladder surface glycosaminoglycans: an epithelial permeability barrier. The Journal of Urology Baltimore v. 143, p. 139-142, 1990.

PERKOWSKI, S.Z. Sedation and anesthesia protocols for feline emergencies. In: NAVC Proceedings 2007, North American Veterinary Conference International Veterinary Information Service, New York: Ithaca, 2007.

PINHEIRO, A.P. Doença do tracto urinário inferior felino: um estudo retrospectivo. 2009. Dissertação (Mestrado em Ciências Veterinárias) - Escola de Ciências Agrárias e Veterinárias, Universidade de Trás-os-Montes e Alto Douro, Vila Real.

POST, K. Feline urological syndrome. Canine Veterinary Journal v.20, p.109-112, 1979.

RECHE Jr., A.; BUFFINGTON, C.A.T. Increased tyrosine hydroxylase immunoreactivity in the locus coeruleus of cats with interstitial cystitis. The Journal of Urology v.159, p.1045-1047, 1998.

RECHE Jr., A.; HAGIWARA, M.; MAMIZUKA, E. Estudo clínico da doença do trato urinário inferior em gatos domésticos de São Paulo. Brazilian Journal of Veterinary Research and Animal Science v.35, n.2, p.34-40, 1998.

RECHE Jr., A.; HAGIWARA, M.K. Histopatologia e morfometria da bexiga de gatos com doença idiopática do trato urinário inferior (DITUI). Ciência Rural v.31, n.6, p.1045-1049, 2001.

RECHE Jr., A. Cistite intersticial. In: SOUZA, H.J.M. (ed.) Coletâneas em Medicina e Cirurgia Felina. Rio de Janeiro: L.F. Livros de Veterinária p.43-49, 2003. 
RECHE Jr., A.; HAGIWARA, M.K. Semelhanças entre a doença idiopática do trato urinário inferior dos felinos e a cistite intersticial humana. Ciência Rural v.34, n.1, p.315-321, 2004.

RECHE Jr., A. A orbifloxacina no tratamento das cistites bacterianas em gatos domésticos. Ciência Rural v.35, n.6, p.1325-1330, 2005.

RIESER, T.M. Urinary tract emergencies. The Veterinary Clinics of North America: Small Animal Practice v.35, p.359-373, 2005.

RHODES, D.C.J.; HINSMAN, E.J.; RHODES, J.A. et al. Urinary Tamm-Horsfall glycoprotein concentration in normal and urolithiasis-affected male cats determined by an ELISA. Veterinary Medicine v. 39, n. 8, p. 621-34, 1992.

ROSS, L.A. The protocol of treating cats with urethral obstruction. Veterinary Medicine v.85, n.11, p.1206-1215, 1990.

SANCHES, P.C.R.; MOFFA, P.J. O eletrocardiograma nos distúrbios eletrolíticos e modificações eletrocardiográficas provocadas pelos medicamentos. In: Ramires, J. A.F.; Oliveira, S.A. (eds.) Eletrocardiograma: normal e patológico. 1aㅡ. Ed., São Paulo: Roca, p.902 - 905, 2001.

SATO, R.; SOETA, S.; SYUTO, B. et al. Urinary excretion of N-Acetyl-B-Dglucosaminidase and its isoenzymes in cats with urinary disease. Journal of Veterinary Medical Science v.64, n.4, p.367-371, 2002.

SCHAER, M. The Use of Regular Insulin in the Treatment of Hyperkalemia in Cat with Urethral Obstruction. Journal of the American Animal Hospital Association New York v.11, p.106-109, 1975.

SCHAER, M. Electrocardiographic abnormalities and treatment. Veterinary Clinics of North America: Small Animal Practice v. 7, n. 2, p. 407-414, 1977.

SKOCH, E.R.; CHANDLER, G.M.; RICHARDSON, D.P. Influence of diet on urine pH and the feline urological syndrome. Journal of Small Animal Practice v.32, n.8, p.413-419,1991.

SMITH, B. H.; BUFFINGTON, C. T.; MARKWELL, P. J. The effect of diet on lower urinary diseases in cats. Wathan Center for Pet Nutrition. Journal of Nutrition v.128, n.18, p. 64-72, 1998.

SOARES, J.A.; LEITE, R.M.C.; RABELO, R.C. Abordagem otimizada do felino obstruído. In: Fundamentos de Terapia Intensiva Veterinária em Pequenos Animais - Condutas no Paciente Crítico. Rio de Janeiro: LF Livros p.465-469, 2005.

SOUZA, H.J.M. Condutas na desobstrução uretral. In: Souza M. J. H. (ed.) Coletânea em medicina e cirurgia felina. Rio de Janeiro: Livros de Veterinária p. 67-88, 1998. 
SOUZA, H.J.M. Coletâneas em Medicina e Cirurgia Felina. Rio de Janeiro: L.F. Livros, 2003, 179p.

STEAGALL, P.V.M.; CARNICELLI, P.; TAYLOR, P.M. et al. Effects of subcutaneous methadone, morphine, buprenorphine or saline on thermal and pressure thresholds in cats. Journal Veterinary Pharmacol Therapy v. 29, p. 531-537, 2006.

STEVENSON, A.E. The incidence of urolithiasis in cats and dogs and the influence of diet in the formation and prevention of recurrence. PhD thesis, Institute of Urology and Nephrology, University College London. 2001.

STEVENSON, A.E.; MARKWELL, P. A comparison of urine parameters produced by healthy Labradors and Miniature Schnauzers. American Journal of Veterinary Research v.62, p. 1782-1786, 2001.

STURGESS, C.P; HESFORD, A.; OWEN, H., et al. An investigation into the effects of storage on the diagnosis of crystalluria in cats. Journal of Feline Medicine and Surgery v.3, p.81-85, 2001.

THOMAS, C. L. Dicionário Médico Enciclopédico Taber. 17ํㅡㄹ Ed., São Paulo: Manole p.2279, 2000.

TUZIO, H. Pyelonephritis. In: Lappin, M.R. Feline Internal Medicine Secrets. $2^{\text {nd }}$ Ed., Philadelphia: Hanley \& Belfus p. 203 - 207, 2001.

WALDRON, D.R. Bexiga. In: Slatter, D. (ed.) Manual de Cirurgia de Pequenos Animais 2a Ed. São Paulo: Manole p. 1723-1736, 1998.

WEICHSELBAUM, R.C.; FEENEY, D.A.; JESSEN, C.R. et al. Evaluation of the morphologic characteristics and prevalence of canine urocystoliths from a regional urolith center. American Journal Veterinary Research v. 59, p. 379-387, 1998.

WESTROPP, J.L.; BLAISDELL, J.L.; BUFFINGTON, C.A. Analysis of plug material from cats suffering urethral obstruction. In: ADVANCES IN VETERINARY MEDICINE, 1996, Columbus. Abstracts. Columbus: The Ohio State UniversityCollege of Veterinary Medicine, 1996. p.IM-8.

WESTROPP, J.L; BUFFINGTON, T.C.A.; CHEW, D. Feline Lower Urinary Tract Diseases In: Ettinger, S.J. e Feldman, E.C. (eds.) Textbook of Veterinary Internal Medicine, $6^{\text {th }}$ Ed., St. Lowis: Elsevier Saunders v.2, p. 1828-2850, 2005.

WESTROPP, J.L. Gatos com sintomatologia do tracto urinário inferior. Veterinary Focus v.17, n.1, 2007.

WILLIAMS, J. Surgical management of blocked cats: Which approach and when? Journal of Feline Medicine and Surgery v.11, p.14-22, 2009. 
WOUTERS, F.; BARROS, C.S.L.; WOUTERS, A.T.B. et al. Síndrome urológica felina: 13 casos. Ciência Rural v.28, n.3, p.497-500, 1998.

ZIGMOND, M.J.; FINLAY, J.M.; SVED, A.F. Neurochemical studies of central noradrenergic responses to acute and chronic stress-implications for normal and abnormal behavior. In: FRIDMAN, M.J.; CHARNEY, D.S.; DEUTCH, A.Y. Neurobiological and clinical consequences of stress - from normal adaptation to post-traumatic stress disorder. Philadelphia: Lippincott-Raven p.45-60, 1995. 